\title{
Enrichment of trace metals from acid sulfate soils in sediments of the Kvarken Archipelago, eastern Gulf of Bothnia, Baltic Sea
}

\author{
Joonas J. Virtasalo ${ }^{1}$, Peter Österholm ${ }^{2}$, Aarno T. Kotilainen ${ }^{1}$, and Mats E. Åström ${ }^{3}$ \\ ${ }^{1}$ Marine Geology, Geological Survey of Finland (GTK), Espoo, 02150, Finland \\ ${ }^{2}$ Department of Geology and Mineralogy, Åbo Akademi University, Turku, 20500, Finland \\ ${ }^{3}$ Department of Biology and Environmental Science, Linnaeus University, Kalmar, 39182, Sweden
}

Correspondence: Joonas J. Virtasalo (joonas.virtasalo@gtk.fi)

Received: 17 June 2020 - Discussion started: 21 July 2020

Revised: 21 October 2020 - Accepted: 24 October 2020 - Published: 7 December 2020

\begin{abstract}
Rivers draining the acid sulfate soils of western Finland are known to deliver large amounts of trace metals with detrimental environmental consequences to the recipient estuaries in the eastern Gulf of Bothnia, northern Baltic Sea. However, the distribution of these metals in the coastal sea area and the relevant metal transport mechanisms have been less studied. This study investigates the spatial and temporal distribution of metals in sediments at nine sites in the Kvarken Archipelago, which is the recipient system of Laihianjoki and Sulvanjoki rivers that are impacted by acid sulfate soils. The contents of $\mathrm{Cd}, \mathrm{Co}, \mathrm{Cu}, \mathrm{La}, \mathrm{Mn}, \mathrm{Ni}$, and $\mathrm{Zn}$ increased in the cores during the 1960s and 1970s as a consequence of intensive artificial drainage of the acid sulfate soil landscape. Metal deposition has remained at high levels since the 1980s. The metal enrichment in sea floor sediments is currently visible at least $25 \mathrm{~km}$ seaward from the river mouths. Comparison with sediment quality guidelines shows that the metal contents are very likely to cause detrimental effects on marine biota more than $12 \mathrm{~km}$ out from the river mouths. The dynamic sedimentary environment of the shallow archipelago makes these sediments potential future sources of metals to the ecosystem. Finally, the strong association of metals and nutrients in the same sediment grain size class of 2-6 $\mu \mathrm{m}$ suggests that the transformation of dissolved organic matter and metals to metal-organic aggregates at the river mouths is the key mechanism of seaward trace metal transport, in addition to co-precipitation with Mn oxyhydroxides identified in previous studies. The large share of terrestrial organic carbon in the total organic $\mathrm{C}$ in these sediments (interquartile range $-39 \%-48 \%$ ) highlights the importance of riverine organic matter supply. These findings are impor-
\end{abstract}

tant for the estimation of environmental risks and the management of biologically sensitive coastal sea ecosystems.

\section{Introduction}

Acid sulfate (AS) soils are regarded as the nastiest soils in the world due to their ability to generate sulfuric acid and extremely low $\mathrm{pH}$ conditions in porewater and surface waters (Dent and Pons, 1995). The global distribution of these soils is estimated at 50 million ha, including areas in Australia, Africa, Central and South America, South and Southeast Asia, and Northern and Western Europe (Andriesse and van Mensvoort, 2006; Michael et al., 2017). In Europe, the largest occurrences of AS soils are probably found in Finland, where current estimates point to AS soils occupying an area of the order of 1 million ha (Anton Boman, personal communication, 2020).

AS soils in northern Europe are organic-rich sulfidebearing muds that were originally deposited in the Baltic Sea during its brackish-water phase, which, in the Gulf of Bothnia, began ca. 7000 years ago (Virtasalo et al., 2007; Häusler et al., 2017). These muds have since emerged above sea level as a result of rapid land uplift (today 4-9 $\mathrm{mm} \mathrm{yr}^{-1}$ in western Finland; Mäkinen and Saaranen, 1998; Kakkuri, 2012). Artificial drainage and reclamation of these lands for farming purposes, which was particularly intensive in Finland in the 1960s and 1970s, has caused a significant lowering of the groundwater level (Saarinen et al., 2010; Yu et al., 2015). The groundwater lowering has enabled rapid oxidation of metal sulfide minerals that are abundant in these muds, pro- 
ducing $\mathrm{H}_{2} \mathrm{SO}_{4}$ and resulting in AS soils with a $\mathrm{pH}<4$ (YliHalla et al., 1999; Sohlenius and Öborn, 2004; Boman et al., 2010). Under these extremely acidic conditions, large quantities of metals are released to the porewater due to the oxidative dissolution of metal sulfides and weathering of silicate minerals. Particularly during high water flow conditions in spring and autumn, acidic porewater rich in metals (e.g. Al, $\mathrm{Cd}, \mathrm{Co}, \mathrm{La}, \mathrm{Mn}, \mathrm{Ni}$, and $\mathrm{Zn}$ ) is flushed to recipient streams, with detrimental ecological consequences for biodiversity and the community structure of fish, benthic invertebrates, and aquatic plants (Hudd and Kjellman, 2002; Fältmarsch et al., 2008; Sutela and Vehanen, 2017). Climate change is predicted to result in increasing precipitation and river discharges during winter in Finland; increasing temperatures and evapotranspiration during summer (Olsson et al., 2015) are likely to enhance the drying and oxidation of sulfides in AS soils (Österholm and Åström, 2008; Job et al., 2020). It is thus expected that the acidic runoff and metal loading from AS soils will increase with climate change (Saarinen et al., 2010; Nystrand et al., 2016).

When acidic metal-rich river waters from the boreal AS soil landscape are discharged to estuaries with higher $\mathrm{pH}$ and salinity, the metals are complexed with organic matter or co-precipitated with $\mathrm{Al}, \mathrm{Fe}$, and $\mathrm{Mn}$ oxyhydroxides and consequently deposited in sediments ( $\mathrm{s} s t o ̈ m$ and Corin, 2000; Nystrand et al., 2016). Low-density organic aggregates have the capacity to be transported across estuarine gradients, and their role in the seaward trace metal transport has been highlighted in recent studies, particularly in the Baltic Sea (Gustafsson et al., 2000; Jokinen et al., 2020). It has been shown that trace metals from AS soils are enriched in sea floor sediments near the mouths of rivers draining from the coastal plains of western Finland compared to background values and to the parent AS soil material (Nordmyr et al., 2008a, b), with documented deteriorative effects on local benthic invertebrate communities (Wallin et al., 2015). Less is known, however, about the distribution of these metals in sediments further out from the river mouths, although this information is important for the estimation of ecotoxicological effects and the management of biologically sensitive coastal sea ecosystems (e.g. de Souza Machado et al., 2016). The distribution pattern of the metals is also informative about the seaward metal transport mechanisms.

Permanent sediment deposition in the eastern coastal Gulf of Bothnia is restricted to small patches due to shallow water depths and the openness of the area to dominant southwesterly winds (waves; Kotilainen et al., 2012). This pattern of sediment deposition and erosion is in slow but constant change due to the uplift, which makes these recent sediment patches prone to remobilization and potential secondary sources of metals to the marine ecosystem. In addition, the building and maintenance of offshore infrastructure such as shipping lanes require repeated and, in the long term, more extensive dredging, which can result in the resuspension and redistribution of metals in the environment (Lehoux et al., 2020). Finally, climate models project stronger westerly winds and a shorter ice season in winter over Northern Europe (Ruosteenoja et al., 2019), which have the potential to increase sea floor erosion and sediment redistribution in the study area. Therefore, understanding the transport and distribution of metals in sea floor sediments is particularly important in the dynamic eastern coastal Gulf of Bothnia.

The aim of this study is to assess, for the first time, the distribution of trace metals in sea floor sediments, with distances from the mouths of rivers running through a boreal AS soil landscape. The studied sea area is in the Kvarken Archipelago, off the town of Vaasa, in the eastern Gulf of Bothnia, which receives significant amounts of metals from the Laihianjoki and Sulvanjoki rivers that are among the most AS-soil-impacted rivers in Finland and Europe (Roos and Åström, 2005). The focus is on sediments deposited before and after the intensive artificial drainage of the AS soil landscape beginning in the 1960s. The focus is further on metals that are known to be extensively leached from AS soils $(\mathrm{Al}, \mathrm{Cd}, \mathrm{Co}, \mathrm{Cu}, \mathrm{La}, \mathrm{Mn}, \mathrm{Ni}$, and $\mathrm{Zn}$ ) and much less so from the local industry and other human activities in the area (see Åström and Björklund, 1997; Åström and Corin, 2000; Österholm and Åström, 2002).

\section{Study area}

The Kvarken Archipelago is located in the Gulf of Bothnia, where it marks the border between the Bothnian Sea in the south and the Bothnian Bay in the north (Fig. 1). The area was covered by the Fennoscandian Ice Sheet during the latest (Weichselian) glaciation, which retreated from the area ca. 10400 years ago (Sauramo, 1929; Saarnisto and Saarinen, 2001; Stroeven et al., 2016). Kvarken is a UNESCO World Heritage Site because it is considered as a prime location that demonstrates the effects of rapid glacio-isostatic uplift (today ca. $8 \mathrm{~mm} \mathrm{yr}^{-1}$; Mäkinen and Saaranen, 1998; Kakkuri, 2012) on shoreline displacement and changes in the coastal landscape. During and just after deglaciation, the archipelago was submerged to a water depth of $250-280 \mathrm{~m}$, whereas today the area is very shallow $(<25 \mathrm{~m})$ and shoaly, with approximately 7000 islands and islets (Breilin et al., 2005; Ojala et al., 2013). The rapid uplift has led to strong sea floor erosion and sediment transport to deep areas further offshore. Till covers ca. $70 \%$ of the modern sea floor in the archipelago (Kotilainen et al., 2012). Glaciolacustrine varved silts and clays and postglacial lacustrine weakly layered silty clays cover ca. $18 \%$ of the sea floor, whereas bedrock outcrops are rare (3\% of the sea floor). Patches of recent mud deposition cover only ca. $8 \%$ of the sea floor (Kotilainen et al., 2012).

The Kvarken Archipelago belongs to the continental subarctic climate zone with severe dry winters and almost warm summers. The mean annual air temperature is $4.2^{\circ} \mathrm{C}$, with the mean minimum temperature of $2.1^{\circ} \mathrm{C}$ and the mean 


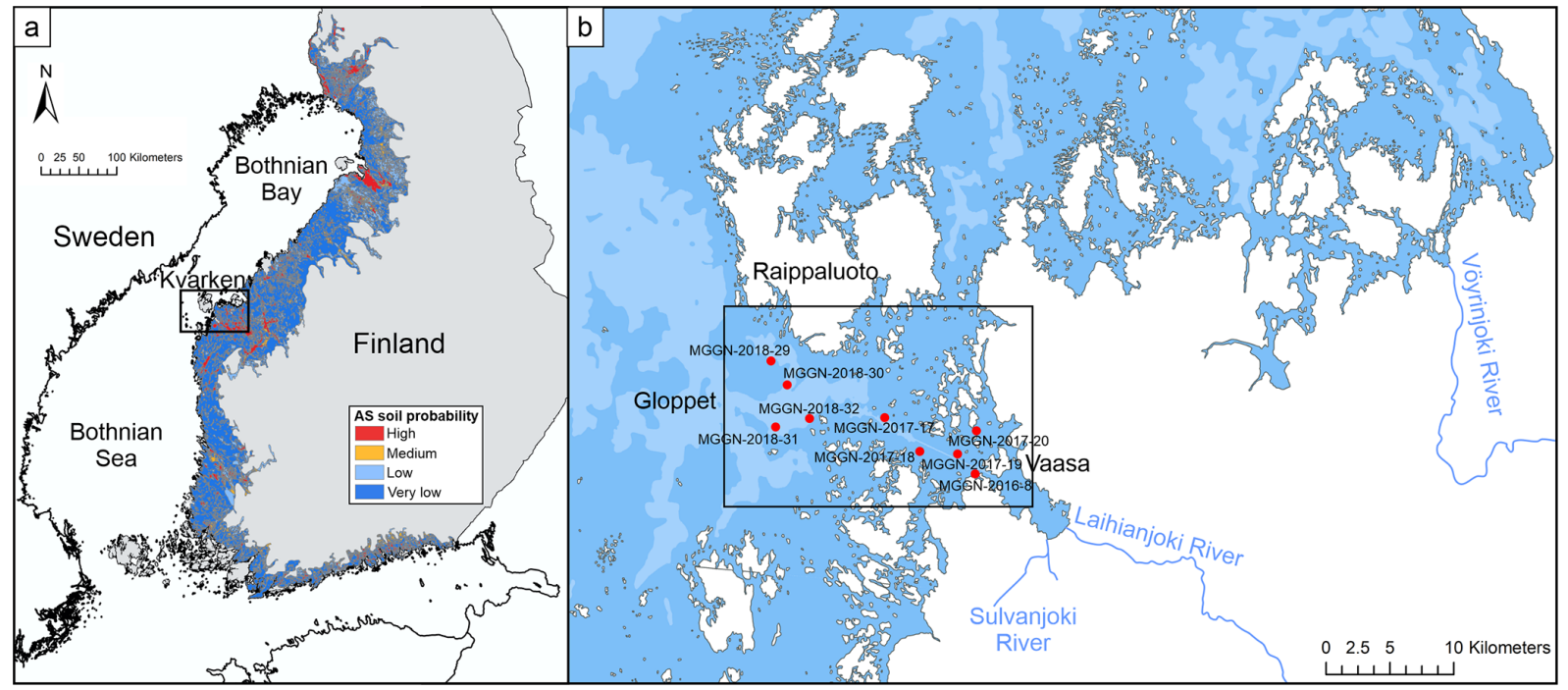

Figure 1. Maps of the Baltic Sea and study area. (a) Map of the Baltic Sea and the probability of acid sulfate soil occurrence in Finland. Black square indicates the location of the study area on the west coast of Finland. (b) Nautical chart of the study area in the Kvarken Archipelago. Red dots indicate the sediment coring sites of this study. Sources: acid sulfate soil probability map - Geological Survey of Finland, 2018; nautical chart - Finnish Transport Agency, 2017

maximum temperature of $6.6^{\circ} \mathrm{C}$ during the period $1981-$ 2010 (Pirinen et al., 2012). The mean annual precipitation is $497 \mathrm{~mm}$. The Bothnian Sea freezes on an annual basis and remains frozen for up to $140-150 \mathrm{~d} \mathrm{yr}^{-1}$. The annual mean sea surface salinity in the archipelago ranges between 3.5 and 4 , and the annual mean sea surface temperature is between 3.5 and $7{ }^{\circ} \mathrm{C}$. The sea is essentially non-tidal, but irregular water level fluctuations of as much as $\pm 1.5 \mathrm{~m}$ take place as a result of variations in wind and atmospheric pressure. Stratification of the shallow waters is governed by a thermocline that develops each summer. The area is generally less affected by eutrophication and the associated sea floor oxygen deficiency, which are widespread in the southern and central Baltic Sea (Lundberg et al., 2009).

\section{Materials and methods}

\subsection{Sediment coring}

The fieldwork was carried out during the summers of 20162018 on-board the research vessel Geomari of the Geological Survey of Finland. Geomari is equipped with a marine geological seismoacoustic survey system, which includes a Meridata $28 \mathrm{kHz}$ pinger and Massa TR-61A $3.5-8 \mathrm{kHz}$ CHIRP sub-bottom profilers that were essential for the identification of coring sites that are representative of recent sediment deposition.

Altogether, nine sediment cores (Table 1) were collected using a Gemax twin-barrel short gravity corer (core diameter $9 \mathrm{~cm}$ ), which preserves the soft sediment surface so that it is essentially undisturbed. One core of each twin was cut in half, lengthwise, and cleaned for sedimentological description and photography, whereas the other core was sectioned, using a rotary device, into $1 \mathrm{~cm}$ sample slices. The sample slices were stored in the cold $\left(4-6{ }^{\circ} \mathrm{C}\right)$ and dark until the shore-based laboratory analysis, which took place within a few months of the sample collection.

\subsection{Laboratory analyses}

Sample slices were analysed for ${ }^{137} \mathrm{Cs}$ activity content in order to constrain the sediment chronology in each core. The ${ }^{137} \mathrm{Cs}$ activity of untreated samples was measured for $60 \mathrm{~min}$, using a BrightSpec bMCA-USB pulse height analyser coupled to a well-type $\mathrm{NaI}(\mathrm{Tl})$ detector at the Geological Survey of Finland (Ojala et al., 2017). Each core was analysed, starting from the uppermost sample slice and progressing downward until near zero (background) activity levels were measured in at least three consecutive samples. No corrections were applied for the results because the aim was only to detect relative ${ }^{137} \mathrm{Cs}$ activity peaks. Due to the possible postdepositional downward transport of ${ }^{137} \mathrm{Cs}$ through bioturbation and diffusion (Holby and Evans, 1996; Klaminder et al., 2012), the depth of peak ${ }^{137}$ Cs activity (rather than the initial increase) was assumed to represent the fallout from the 1986 Chernobyl nuclear disaster. Sample slices for each core were classified into two groups, namely those deposited in 1986 and later and those deposited before 1986. The samples deposited before 1986 were further classified as those deposited after and before the year 1960, by calculating the average thickness of sediment deposited annually after 1986 in each core and estimating the depth of 1960 by assuming a constant sedimentation rate for that core. This approach po- 
Table 1. Sediment coring locations, water depths, coring dates, core lengths, and distances to the nearest river mouth.

\begin{tabular}{|c|c|c|c|c|c|c|c|}
\hline Sediment core & $\begin{array}{r}\text { Latitude } \\
\text { ETRS-TM35FIN }\end{array}$ & $\begin{array}{r}\text { Longitude } \\
\text { ETRS-TM35FIN }\end{array}$ & $\begin{array}{r}\text { Water } \\
\text { depth }(m)\end{array}$ & Coring date & $\begin{array}{r}\text { Core } \\
\text { length }(\mathrm{cm})\end{array}$ & $\begin{array}{r}\text { Distance to } \\
\text { river }(\mathrm{km})\end{array}$ & 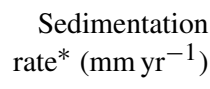 \\
\hline MGGN-2016-8 & $63^{\circ} 05.040$ & $21^{\circ} 32.182$ & 6 & 4 August 2016 & 40 & 8.2 & $>13$ \\
\hline MGGN-2017-17 & $63^{\circ} 06.828$ & $21^{\circ} 23.579$ & 10 & 3 July 2017 & 38 & 14.2 & 5.3 \\
\hline MGGN-2017-18 & $63^{\circ} 05.781$ & $21^{\circ} 27.339$ & 8 & 3 July 2017 & 40 & 12.6 & 6.9 \\
\hline MGGN-2017-19 & $63^{\circ} 05.557$ & $21^{\circ} 30.567$ & 7 & 3 July 2017 & 40 & 10.1 & 4.0 \\
\hline MGGN-2017-20 & $63^{\circ} 06.640$ & $21^{\circ} 32.186$ & 5 & 3 July 2017 & 40 & 10.0 & 4.4 \\
\hline MGGN-2018-29 & $63^{\circ} 08.983$ & $21^{\circ} 12.564$ & 17 & 8 August 2018 & 30 & 26.3 & 4.8 \\
\hline MGGN-2018-30 & $63^{\circ} 08.023$ & $21^{\circ} 14.327$ & 14 & 8 August 2018 & 40 & 24.7 & 2.7 \\
\hline MGGN-2018-31 & $63^{\circ} 06.411$ & $21^{\circ} 13.894$ & 17.5 & 10 August 2018 & 40 & 23.8 & 2.3 \\
\hline MGGN-2018-32 & $63^{\circ} 06.675$ & $21^{\circ} 16.433$ & 15 & 10 August 2018 & 42 & 21.4 & 1.7 \\
\hline
\end{tabular}

* Sedimentation rate is calculated on the basis of the depth of ${ }^{137}$ Cs peak activity due to the 1986 Chernobyl disaster in each core.

tentially slightly overestimates the depth of the year 1960 because of the increasing sediment compaction with core depth. The approach should, therefore, be viewed as conservative to sediments deposited before the year 1960 .

After the non-destructive ${ }^{137} \mathrm{Cs}$ analysis, fresh sample slices were freeze-dried, homogenized, and halved, with one half analysed for multi-element composition and the other for grain size distribution at the commercial laboratory of Eurofins Labtium Ltd (Kuopio, Finland). The material for multi-element analysis was sieved through a $63 \mu \mathrm{m}$ mesh, and $0.2 \mathrm{~g}$ of the passed-through fraction was digested in a four-acid mixture of hydrofluoric acid, perchloric acid, hydrochloric acid, and nitric acid (USGS methods T01 and T20). After evaporation of the acids at $160^{\circ} \mathrm{C}$, the resulting gel was dissolved in $1 \mathrm{M} \mathrm{HNO}_{3}$ and analysed for element concentrations by inductively coupled plasma mass spectrometry (ICP-MS) or inductively coupled plasma optical emission spectrometry (ICP-OES). Ag, As, Bi, Cd, Ce, Dy, Er, Eu, Gd, Hf, Ho, La, Lu, Nb, Nd, Pr, Sb, Sm, Sn, $\mathrm{Ta}, \mathrm{Tb}, \mathrm{Th}, \mathrm{Tl}, \mathrm{Tm}, \mathrm{U}$, and $\mathrm{Yb}$ were analysed by ICP-MS, whereas $\mathrm{Al}, \mathrm{Ba}, \mathrm{Be}, \mathrm{Ca}, \mathrm{Co}, \mathrm{Cr}, \mathrm{Cu}, \mathrm{Fe}, \mathrm{K}, \mathrm{Li}, \mathrm{Mg}, \mathrm{Mn}, \mathrm{Mo}$, $\mathrm{Na}, \mathrm{Ni}, \mathrm{P}, \mathrm{Pb}, \mathrm{Rb}, \mathrm{S}, \mathrm{Sc}, \mathrm{Sr}, \mathrm{Ti}, \mathrm{V}, \mathrm{Y}, \mathrm{Zn}$, and $\mathrm{Zr}$ were analysed by ICP-OES. Because HF dissolves silicate minerals, the digestion is considered as being a "near-total digestion" (Hall et al., 1996). The commercial sediment reference materials of QCGBMS304-6, QCMESS-4, QCNIST8704, and CO153B and in-house standards were used for assessing measurement accuracy. Element concentrations for all reference materials measured with each sample batch fell well within $\pm 10 \%$ of the certified values. Mercury was measured separately by $\mathrm{HNO}_{3}$ leach of $0.2 \mathrm{~g}$ samples through thermal decomposition, amalgamation, and atomic absorption spectrometry (US EPA method 7473). Solid-phase contents of carbon and nitrogen in the samples were analysed by thermal combustion elemental analysis (TCEA). The pools of inorganic $\mathrm{C}$ and $\mathrm{N}$ are negligible in this setting (Virtasalo et al., 2005; Jilbert et al., 2018); hence, no decalcification was conducted, and the total contents are considered equal to organic $\mathrm{C}$ and $\mathrm{N}$. Experimental precision for each element based on the standard deviations of duplicate analyses of selected samples is provided in Supplement.

To quantify the proportions of terrestrial plant-derived $\left(\% \mathrm{OC}_{\text {terr }}\right)$ and phytoplankton-derived organic matter in the $\mathrm{C}$ pool, a simple binary mixing model was applied for the molar $\mathrm{N} / \mathrm{C}$ ratio, assuming end-member values of $(\mathrm{N} / \mathrm{C})_{\text {terr }}=0.04$ and $(\mathrm{N} / \mathrm{C})_{\text {phyt }}=0.13$, following Goñi et al. (2003) and Jilbert et al. (2018):

$\% \mathrm{OC}_{\text {terr }}=\frac{(\mathrm{N} / \mathrm{C})_{\text {sample }}-(\mathrm{N} / \mathrm{C})_{\text {phyt }}}{(\mathrm{N} / \mathrm{C})_{\text {terr }}-(\mathrm{N} / \mathrm{C})_{\text {phyt }}} \times 100$.

The model integrates a variety of terrestrial organic matter sources, ranging from fresh vascular plant detritus to more degraded soil organic matter, into a single end member. This is practical since effectively all of the organic matter transported by rivers passes through the soil reservoir before entering the coastal zone, therefore representing a mixture of variably degraded material (Jokinen et al., 2018).

Grain size distribution was determined for selected freezedried samples by wet sieving through $20,6.3,2,0.63,0.2$, and $0.063 \mathrm{~mm}$ ISO $3110 / 1$ test sieves. The samples were pretreated with excess $\mathrm{H}_{2} \mathrm{O}_{2}$ to remove organic matter prior to the analysis. The $<63 \mu \mathrm{m}$ size fraction was further analysed down to $0.6 \mu \mathrm{m}$, using a Micromeritics SediGraph III 5120 $\mathrm{X}$-ray absorption sedimentation analyser. The sieving results were merged with sedimentation data in SediGraph software. Median grain size was calculated according to the geometric Folk and Ward (1957) graphical measures implemented in GRADISTAT 4.0 software (Blott and Pye, 2001). Clay is defined as grains finer than $2 \mu \mathrm{m}$, whereas mud is clay and silt $(<63 \mu \mathrm{m})$ and sand is $63 \mu \mathrm{m}$ to $2 \mathrm{~mm}$ (Blott and Pye, 2012).

\subsection{Statistical analysis}

Element contents below detection were rounded to half the detection limits so that approximate values could be used in the analyses.

In order to explore the relationships between elements in the produced multi-element dataset, a robust compositional 
principal component analysis (PCA) after isometric log ratio (ilr) transformation (Filzmoser et al., 2009) was carried out using the robCompositions 2.0.8 package in the $\mathrm{R} 3.5 .1$ software environment. The resultant loadings and scores were back transformed to the centred log ratio (clr) space for meaningful visualization and interpretation in a compositional biplot (Filzmoser et al., 2018).

Relationships between elements and grain size classes were explored using partial least squares regression 2 (PLSR2; Tenenhaus, 1998), as implemented in the plsdepot 0.1.17 package in the $\mathrm{R}$ 3.5.1 software environment. The PLSR2 results were validated using hierarchical partitioning (Chevan and Sutherland, 1991), as implemented in the hier.part 1.0.4 package (Nally and Walsh, 2004) in R.

\section{Results}

Multi-element and grain size data produced in this study are available from PANGAEA (Virtasalo et al., 2020a, b).

\subsection{Core description}

The sediment cores are composed of typical, soft, organicrich brackish-water mud that is depositing along the Finnish coast. The cores have brownish-grey oxidized surface layers that are $1-3 \mathrm{~cm}$ thick, below which the colour quickly changes to dark grey or black, implying a sharp gradient to reducing conditions (see the Supplement; Virtasalo et al., 2005). The sediments are bioturbated and mottled by small burrows. Thin beds with thicknesses on the centimetre-scale range are visible in places, representing the remnants of the primary sedimentary structure. The thin bedding likely does not record seasonal changes in deposition but rather episodic sea floor reworking by short-lived storm-triggered flows (Virtasalo et al., 2014). No sign of significant erosion or gap in deposition was observed in any of the cores upon visual inspection.

The sediments are poorly sorted. The interquartile range (IQR) of the geometric sorting statistic of all sample slices is 3.0-3.3 $\mu \mathrm{m}$, with a median of $3.1 \mu \mathrm{m}$ (Folk and Ward, 1957; Blott and Pye, 2001). The grain size distributions are rather uniform throughout the cores. The IQR of median grain size of all sample slices is $1.96-2.54 \mu \mathrm{m}$, with a median of $2.18 \mu \mathrm{m}$ (see the Supplement). The sediments are classified as clayey silt (according to Blott and Pye, 2012) and silty clay (according to soil taxonomy; Soil Survey Staff, 1999).

\subsection{Vertical distribution}

Peak ${ }^{137} \mathrm{Cs}$ activity is easily distinguishable in all the studied sediment cores, which permits the confident identification of the depth of the Chernobyl fallout year of 1986 in each core (Fig. 2). The clearly defined activity peak in each core excludes significant sediment reworking and post-event migra- tion of ${ }^{137} \mathrm{Cs}$ and supports the estimation of the depth of the year 1960 by assuming a constant sedimentation rate.

Contents of metals $\mathrm{Cd}, \mathrm{Co}, \mathrm{Cu}, \mathrm{La}, \mathrm{Ni}$, and $\mathrm{Zn}$ generally begin to increase approximately at the depth of the year 1960 in the studied cores (Fig. 2). An exception is MGGN-201719 from the eastern Korshamnsfjärden, close to the rivers, where the metal contents are high and variable, with no clear trend below the core depth of $16 \mathrm{~cm}$ (early 1980s), but show an upward increasing trend above this level. The metals reach particularly high contents in MGGN-2017-20 from Varisselkä at ca. 1986, after which they begin to decrease at that site. In all cores from Korshamnsfjärden (MGGN-201717, MGGN-2017-18, and MGGN-2017-19), the increasing trends of $\mathrm{Co}, \mathrm{Ni}, \mathrm{La}$, and $\mathrm{Zn}$ continue overall to the core top, whereas the increasing trends of $\mathrm{Cu}$ and $\mathrm{Cd}$ level out or begin to decrease at ca. 1986. In cores from farther out at sea in Gloppet (MGGN-2018-29 and MGGN-2018-31), from ca. 1986 to the core tops, the contents of $\mathrm{Co}, \mathrm{Ni}$, and $\mathrm{La}$ vary at high values, whereas $\mathrm{Zn}, \mathrm{Cu}$, and $\mathrm{Cd}$ show a decreasing trend.

Aluminium contents are variable but show no clear trends in the cores except in MGGN-2017-20 from Varisselkä, where the vertical distribution of $\mathrm{Al}$ is similar to that of other metals in that core (Fig. 2).

Manganese contents are high and variable, with an upward increasing trend in cores from Varisselkä and eastern and middle Korshamnsfjärden (MGGN-2017-18, MGGN-201719, and MGGN-2017-20; Fig. 2). In cores from farther out at sea in western Korshamnsfjärden and Gloppet (MGGN2017-17, MGGN-2018-29, and MGGN-2018-31), Mn contents are low, except for a strong increase at the core tops.

Carbon contents increase towards the top in all cores. In cores from Gloppet (MGGN-2018-29 and MGGN-2018$31)$ and from western Korshamnsfjärden (MGGN-2017-17), $\mathrm{C}$ contents range between $2 \%$ and $3 \%$ prior to ca. 1986 and between $3 \%$ and $4 \%$ higher up the cores (Fig. 2). In middle and eastern Korshamnsfjärden (MGGN-2017-18 and MGGN-2017-19), C contents vary between $3 \%$ and $4 \%$ before ca. 1986 and between $4 \%$ and $5 \%$ in the upper core sections. In Varisselkä (MGGN-2017-20), C contents increase strongly between 1960 and 1986 and reach $6 \%$ in the upper section of that core. The terrestrial organic share of the $\mathrm{C}$ content before ca. 1986 is $40 \%-50 \%$ in cores from Gloppet and western and middle Korshamnsfjärden and 50\%-60\% in cores form eastern Korshamnsfjärden and Varisselkä. After ca. 1986, the share of terrestrial organic carbon decreases in all cores, largely mirroring the upward-increasing $\mathrm{C}$ content.

\subsection{Statistical relationships}

Statistical analyses were carried out on the upper core sections that were deposited after the year 1960 because it is clear in the vertical metal content profiles (Fig. 2) that this interval is the most enriched in metals. 

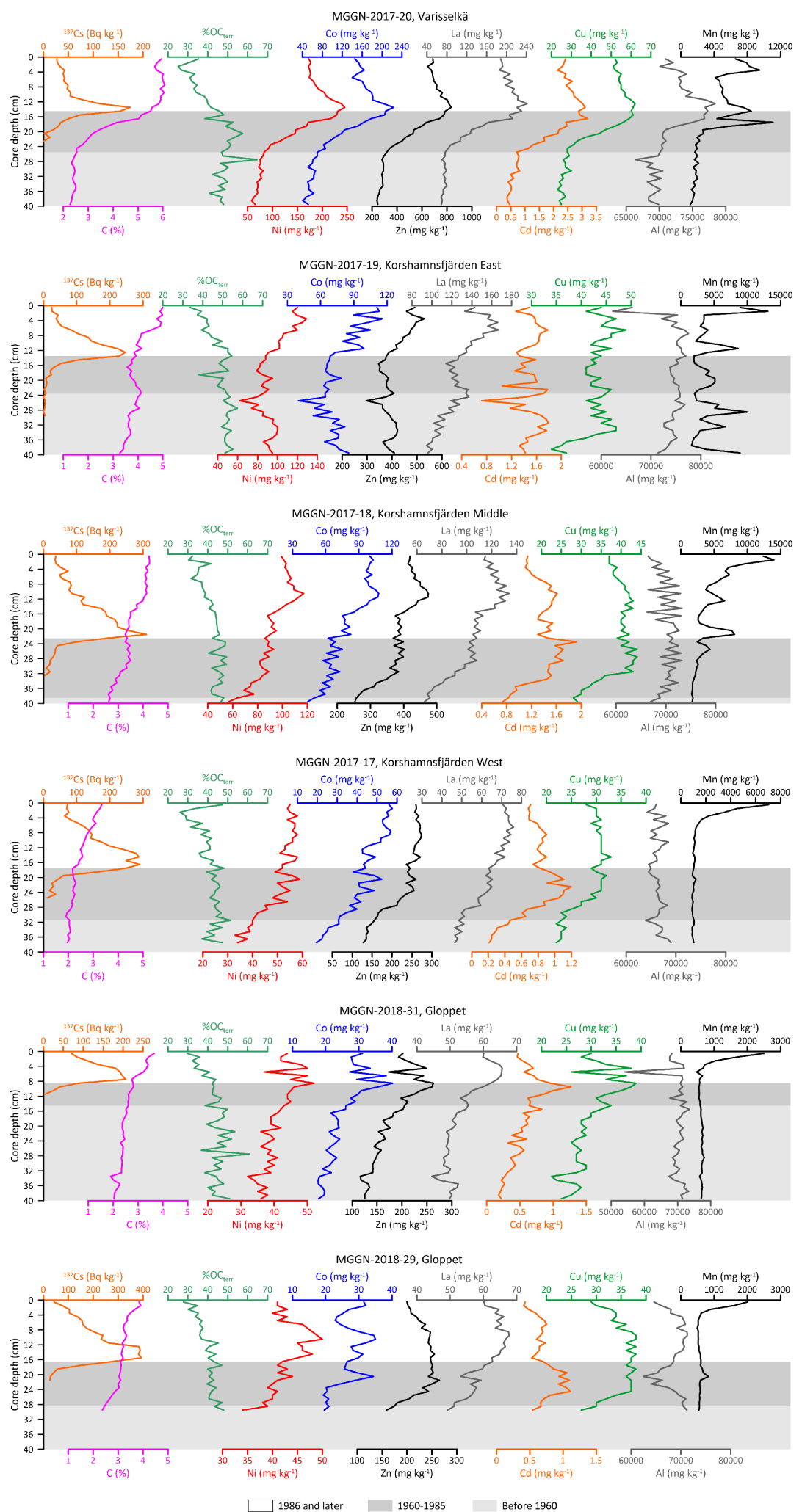

Figure 2. Vertical distributions of ${ }^{137} \mathrm{Cs}$, carbon, the share of terrestrial organic carbon, and the contents of metals typically leached from acid sulfate soils in the $<63 \mu \mathrm{m}$ grain size fraction of representative sediment cores in the Kvarken Archipelago. The cores are arranged according to increasing distance from the Laihianjoki and Sulvanjoki rivers (downward). The dark grey shading indicates the interval deposited between 1960 and 1985, and the light grey shading indicates the interval deposited before the year 1960 in each core. The intervals without shading were deposited in 1986 and later. 


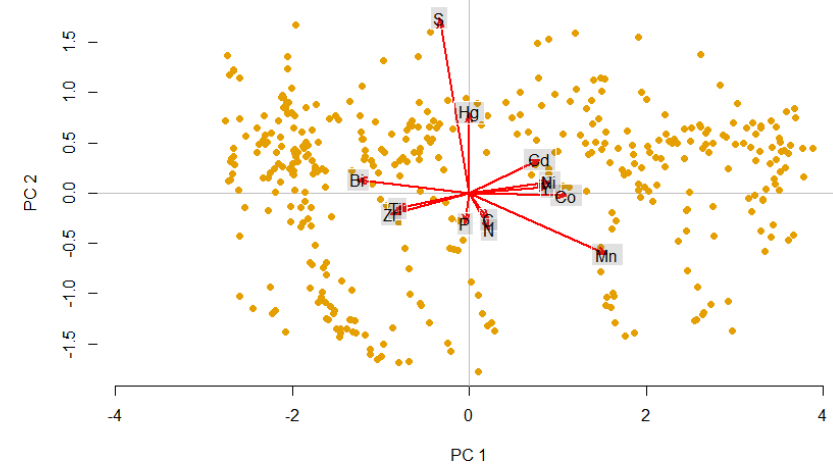

Figure 3. Biplot for robust compositional PCA of 54 elements in sediments deposited after the year 1960. A total of 13 elements with the strongest loadings are shown by arrows.

The first principal component (PC1) of the robust compositional PCA explains $73.7 \%$ of the total variance. The second principal component (PC2) explains $10.7 \%$, whereas the rest of the components each explain less than $6 \%$ of the total variance. The metals $\mathrm{Co}, \mathrm{Ni}$, and $\mathrm{Cd}$ cluster along the positive side of PC1 in the biplot (Fig. 3). In addition, Mn has a strong positive loading on PC1, but it deviates slightly from the other metals. This deviation in Mn is likely explained by its vertical distribution in sediment cores that is similar to the other metals in Varisselkä and in eastern and middle Korshamnsfjärden but different in cores collected farther out at sea (Fig. 2).

A two-component PLSR2 model utilizes $82.3 \%$ of the variance in predictor variables (54 elements) to explain $68.3 \%$ of the variance in response variables (13 grain size classes). The metals $\mathrm{Cd}, \mathrm{Co}, \mathrm{Cu}, \mathrm{Ni}$, and $\mathrm{Zn}$ have strong positive correlations with the grain size classes of 2-4 and 4-6 $\mu \mathrm{m}$ in the PLSR2 (Fig. 4a). Notably, also C and N are positively correlated with these grain size classes.

In concordance with the PLSR2, the hierarchical partitioning analysis shows that the $2-4,4-6$, and $1-2 \mu \mathrm{m}$ classes have the most independent power among grain size classes in predicting $\mathrm{Ni}$ contents and account for $17.8 \%, 13.1 \%$, and $11.8 \%$ of the explained variance, respectively (Fig. 4b). The hierarchical partitioning patterns of the other elements identified in the PLSR2 are similar.

\subsection{Spatial distribution}

Metal contents are compared between core sections deposited before the year 1960 and those deposited in 1986 and later in order to explore the magnitude of recent metal enrichment (Fig. 5). Metal contents decrease towards the bottom in all cores; however, in Varisselkä, and Korshamnsfjärden east and middle, metals do not decrease to low levels comparable to those in western Korshamnsfjärden and Gloppet (Fig. 2). Therefore, mean median metal contents in the pre1960 sections of the four cores from Gloppet (MGGN-2018-
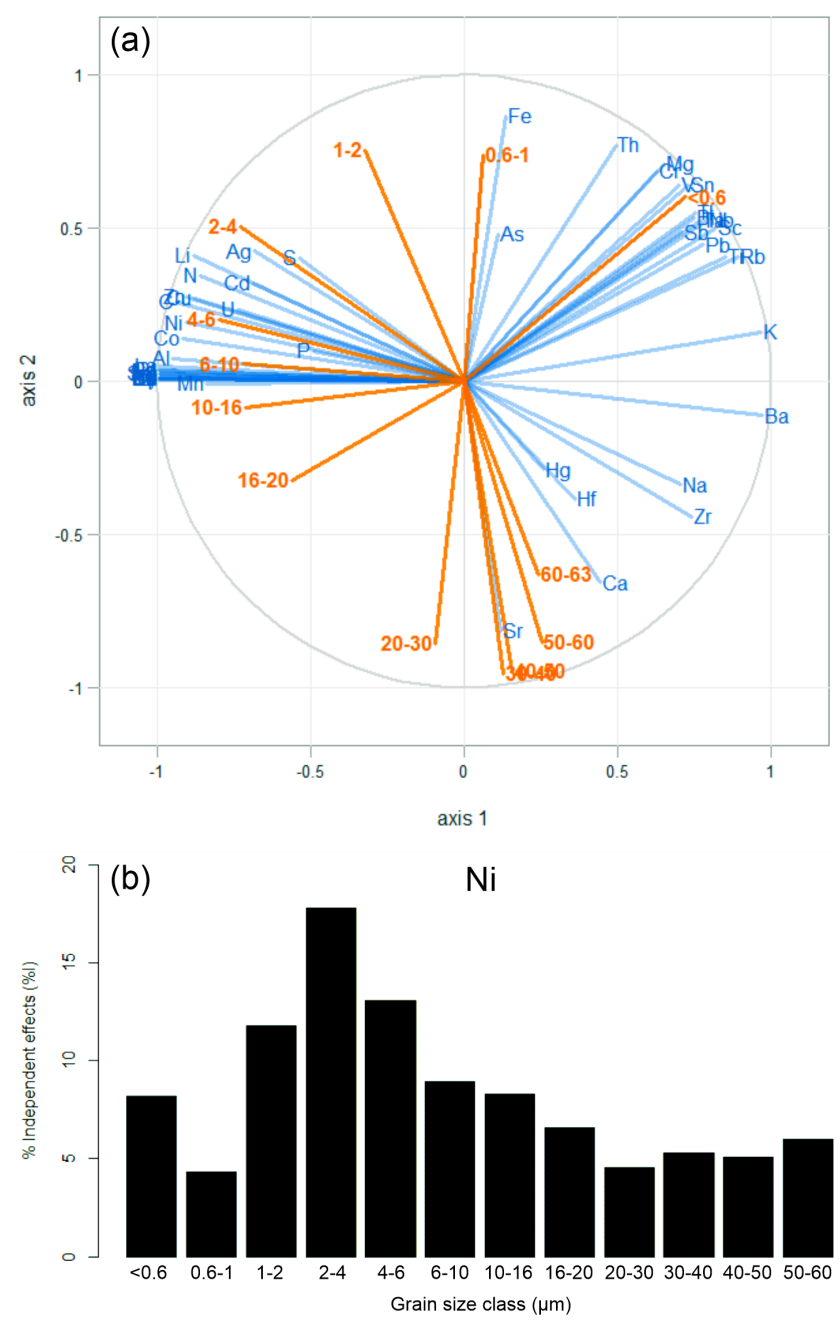

Figure 4. (a) Correlation loading plot of the PLSR2 analysis for 54 predictor variables (blue - elements) and 13 response variables (orange - grain size classes in $\mu \mathrm{m}$ ). (b) Hierarchical partitioning result plot, showing the independent contribution (\%) of each grain size class to predicted $\mathrm{Ni}$ contents.

29, MGGN-2018-30, MGGN-2018-31, and MGGN-201832) are considered to be representative of the local background values and are used here as reference values in the depiction of spatial trends.

Median contents of $\mathrm{Cd}, \mathrm{Co}, \mathrm{Cu}, \mathrm{La}, \mathrm{Mn}, \mathrm{Ni}$, and $\mathrm{Zn}$ in sediment cores decrease with distance from the Laihianjoki and Sulvanjoki rivers in the east (Fig. 5; Table 2; see the Supplement). Comparison between core sections deposited before 1960 and in 1986 and later shows that median contents of $\mathrm{Cd}, \mathrm{Co}, \mathrm{Cu}, \mathrm{La}, \mathrm{Ni}$, and $\mathrm{Zn}$ are higher in the upper sections of all cores, with the difference increasing toward east. However, Mn median contents are enriched only in the upper sections of the four cores closest to the rivers (MGGN-2016-8, MGGN-2017-18, MGGN-2017-19, and MGGN-2017-20), whereas, in the cores further offshore, there is essentially no difference between the upper and lower core sections 


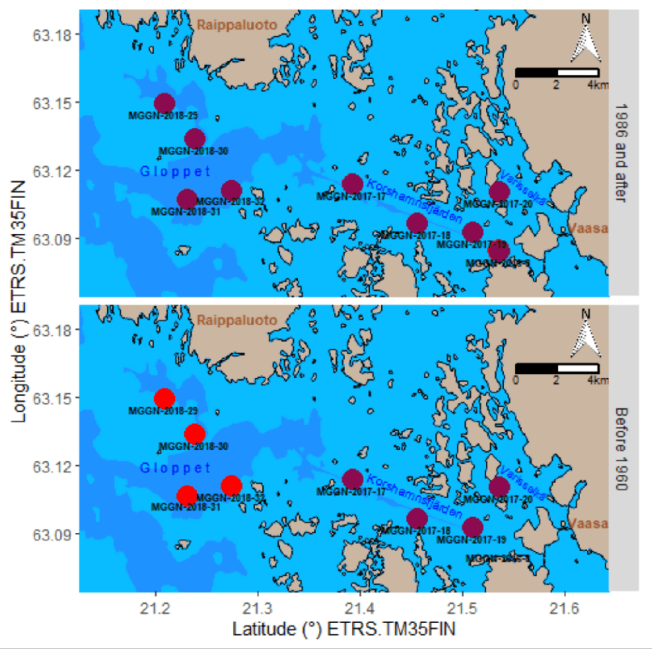

Al

Median content $\left(\mathrm{mg} \mathrm{kg}^{-1}\right)$

- 0

- 20000

40000

60000

Water depth $(\mathrm{m})$

$<10 \mathrm{~m}$

10-25 m

Land

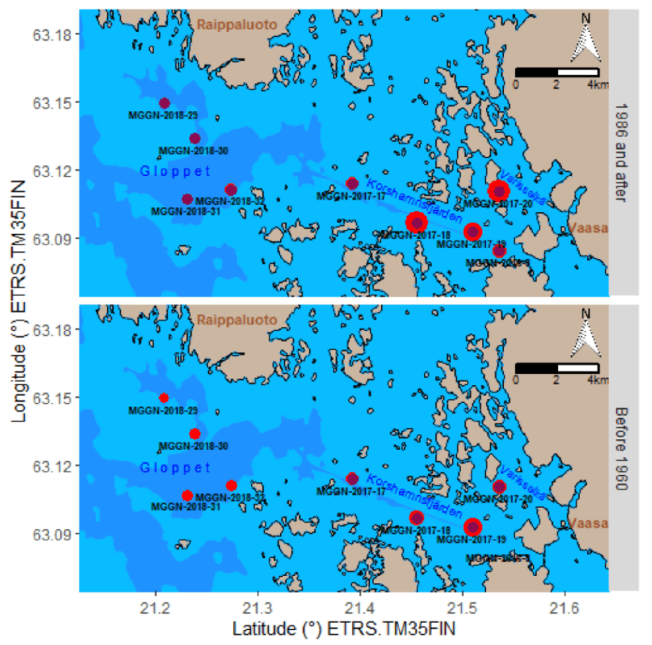

Mn

Median content $\left(\mathrm{mg} \mathrm{kg}^{-1}\right)$

- 0

- 1000

- 2000

3000

- 4000

5000

Water depth $(m)$

$<10 \mathrm{~m}$

10-25 m

Land

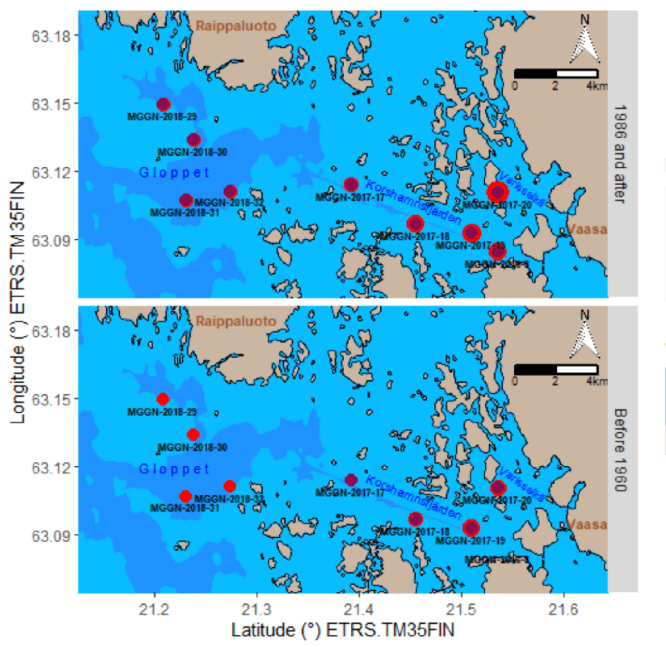

$\mathrm{Ni}$

Median content $\left(\mathrm{mg} \mathrm{kg}^{-1}\right)$

- 0

- 50

- 100

150

Water depth $(m)$

$<10 \mathrm{~m}$

Land

Figure 5. Maps of the sea area off the town of Vaasa, with the median Al, Mn, and Ni contents in the $<63 \mu$ m grain size fraction of core sections deposited before 1960 (lower panels) and in 1986 and after (upper panels) indicated. Bright red dots indicate median contents, whereas the dark red dots indicate mean median contents in the pre-1960 sections of four cores from the Gloppet area (MGGN-2018-29, MGGN-2018-30, MGGN-2018-31, and MGGN-2018-32) in order to highlight the magnitude of enrichment. Note that core MGGN-2016-8 does not contain sediments deposited before 1960. The Laihianjoki and Sulvanjoki rivers are outside the map area, in the southeastern corner. Source: nautical chart - Finnish Transport Agency, 2017. 
Table 2. Median metal and carbon contents in sediment samples, with interquartile ranges in parentheses.

\begin{tabular}{|c|c|c|c|c|c|c|c|c|c|c|c|}
\hline Core or study area & $n$ & $\mathrm{Al}$ & $\mathrm{Cd}$ & Co & $\mathrm{Cu}$ & $\mathrm{La}$ & $\mathrm{Mn}$ & $\mathrm{Ni}$ & $\mathrm{Zn}$ & $\mathrm{C}$ & Reference \\
\hline \multicolumn{12}{|l|}{ MGGN-2016-8 } \\
\hline 1986 and after & 40 & $\begin{array}{r}83650 \\
(72750-87300)\end{array}$ & $\begin{array}{r}1.17 \\
(1.09-1.3)\end{array}$ & $\begin{array}{r}70.1 \\
(63.2-80.1)\end{array}$ & $\begin{array}{r}58.5 \\
(53.7-62.3)\end{array}$ & $\begin{array}{r}187.6 \\
(165.7-201.9)\end{array}$ & $\begin{array}{r}1605 \\
(1422-1893)\end{array}$ & $\begin{array}{r}94 \\
(80.0-105.8)\end{array}$ & $\begin{array}{r}421.5 \\
(372.5-459.3)\end{array}$ & $\begin{array}{r}5.63 \\
(5.16-5.87)\end{array}$ & This study \\
\hline \multicolumn{12}{|l|}{ MGGN-2017-17 } \\
\hline 1986 and after & 17 & $\begin{array}{r}66100 \\
(65400-66900)\end{array}$ & $\begin{array}{r}0.81 \\
(0.71-0.85)\end{array}$ & $\begin{array}{r}52.8 \\
(45.5-55.8)\end{array}$ & $\begin{array}{r}31 \\
(30.0-31.0)\end{array}$ & $\begin{array}{r}71.7 \\
(70.7-73.6)\end{array}$ & $\begin{array}{r}1130 \\
(1080-1640)\end{array}$ & $\begin{array}{r}56 \\
(54.0-57.0)\end{array}$ & $\begin{array}{r}261 \\
(257.0-269.0)\end{array}$ & $\begin{array}{r}2.74 \\
(2.57-3.05)\end{array}$ & This study \\
\hline 1960-1985 & 15 & $\begin{array}{r}66400 \\
(65600-66650)\end{array}$ & $\begin{array}{r}0.91 \\
(0.75-1.08)\end{array}$ & $\begin{array}{r}40 \\
(37.1-43.1)\end{array}$ & $\begin{array}{r}29 \\
(26.0-31.0)\end{array}$ & $\begin{array}{r}61.2 \\
(55.0-63.5)\end{array}$ & $\begin{array}{r}954 \\
(921-1030)\end{array}$ & $\begin{array}{r}50 \\
(45.5-53.0)\end{array}$ & $\begin{array}{r}235 \\
(194.0-244.5)\end{array}$ & $\begin{array}{r}2.18 \\
(2.11-2.22)\end{array}$ & \\
\hline Before 1960 & 6 & $\begin{array}{r}67250 \\
(66300-68050)\end{array}$ & $\begin{array}{r}0.27 \\
(0.24-0.31)\end{array}$ & $\begin{array}{r}23.9 \\
(22.5-25.3)\end{array}$ & $\begin{array}{r}23 \\
(22.3-23.0)\end{array}$ & $\begin{array}{r}47.3 \\
(46.5-49.6)\end{array}$ & $\begin{array}{r}948 \\
(908-1009)\end{array}$ & $\begin{array}{r}38 \\
(35.0-38.8)\end{array}$ & $\begin{array}{r}135.5 \\
(135.0-139.0)\end{array}$ & $\begin{array}{r}2.04 \\
(1.99-2.06)\end{array}$ & \\
\hline \multicolumn{12}{|l|}{ MGGN-2017-18 } \\
\hline 1986 and after & 22 & $\begin{array}{r}69700 \\
(67950-71900)\end{array}$ & $\begin{array}{r}1.41 \\
(1.23-1.52)\end{array}$ & $\begin{array}{r}97.9 \\
(83.5-100.0)\end{array}$ & $\begin{array}{r}40 \\
(39.0-41.0)\end{array}$ & $\begin{array}{r}120 \\
(111.5-124.8)\end{array}$ & $\begin{array}{r}5505 \\
(3823-7273)\end{array}$ & $\begin{array}{r}102.5 \\
(94.3-106.5)\end{array}$ & $\begin{array}{r}421 \\
(396.0-441.5)\end{array}$ & $\begin{array}{r}4.06 \\
(3.50-4.15)\end{array}$ & This study \\
\hline 1960-1985 & 17 & $\begin{array}{r}70700 \\
(69200-71900)\end{array}$ & $\begin{array}{r}1.48 \\
(1.18-1.58)\end{array}$ & $\begin{array}{r}63.4 \\
(59.6-66.8)\end{array}$ & $\begin{array}{r}40 \\
(33.0-43.0)\end{array}$ & $\begin{array}{r}98.2 \\
(80.6-103.0)\end{array}$ & $\begin{array}{r}2350 \\
(1810-2870)\end{array}$ & $\begin{array}{r}84 \\
(77.0-88.0)\end{array}$ & $\begin{array}{r}369 \\
(318.0-384.0)\end{array}$ & $\begin{array}{r}3.29 \\
(2.89-3.36)\end{array}$ & \\
\hline Before 1960 & 1 & 66900 & 0.74 & 43.9 & 29 & 66.1 & 1700 & 57 & 253 & 2.63 & \\
\hline \multicolumn{12}{|l|}{ MGGN-2017-19 } \\
\hline 1986 and after & 13 & $\begin{array}{r}75200 \\
(74100-76100)\end{array}$ & $\begin{array}{r}1.58 \\
(1.48-1.64)\end{array}$ & $\begin{array}{r}95.3 \\
(86.9-105.0)\end{array}$ & $\begin{array}{r}44 \\
(43.0-46.0)\end{array}$ & $\begin{array}{r}151 \\
(139.0-156.0)\end{array}$ & $\begin{array}{r}3510 \\
(3390-5990)\end{array}$ & $\begin{array}{r}115 \\
(102.0-120.0)\end{array}$ & $\begin{array}{r}470 \\
(441.0-489.0)\end{array}$ & $\begin{array}{r}4.53 \\
(4.10-4.89)\end{array}$ & This study \\
\hline 1960-1985 & 11 & $\begin{array}{r}75000 \\
(74200-75550)\end{array}$ & $\begin{array}{r}1.57 \\
(1.34-1.60)\end{array}$ & $\begin{array}{r}66 \\
(64.7-68.2)\end{array}$ & $\begin{array}{r}42 \\
(41.5-44.0)\end{array}$ & $\begin{array}{r}126 \\
(121.5-127.0)\end{array}$ & $\begin{array}{r}3010 \\
(2050-4405)\end{array}$ & $\begin{array}{r}86 \\
(83.5-88.0)\end{array}$ & $\begin{array}{r}377 \\
(362.5-381.5)\end{array}$ & $\begin{array}{r}3.76 \\
(3.75-3.92)\end{array}$ & \\
\hline Before 1960 & 16 & $\begin{array}{r}74400 \\
(73350-74900)\end{array}$ & $\begin{array}{r}1.45 \\
(1.41-1.64)\end{array}$ & $\begin{array}{r}70.7 \\
(63.5-74.6)\end{array}$ & $\begin{array}{r}42.5 \\
(40.0-44.3)\end{array}$ & $\begin{array}{r}107.5 \\
(100.8-117.5)\end{array}$ & $\begin{array}{r}3305 \\
(2333-5240)\end{array}$ & $\begin{array}{r}91.5 \\
(84.0-95.3)\end{array}$ & $\begin{array}{r}389.5 \\
(371.5-411.0)\end{array}$ & $\begin{array}{r}3.64 \\
(3.54-3.77)\end{array}$ & \\
\hline \multicolumn{12}{|l|}{ MGGN-2017-20 } \\
\hline 1986 and after & 14 & $\begin{array}{r}73350 \\
(72750-74700)\end{array}$ & $\begin{array}{r}2.51 \\
(2.39-2.71)\end{array}$ & $\begin{array}{r}164 \\
(153.7-180.5)\end{array}$ & $\begin{array}{r}55 \\
(57.0-62.0)\end{array}$ & $\begin{array}{r}209 \\
(192.5-219.5)\end{array}$ & $\begin{array}{r}5600 \\
(4965-7280)\end{array}$ & $\begin{array}{r}184 \\
(175.3-207.0)\end{array}$ & $\begin{array}{r}707 \\
(687.8-760.0)\end{array}$ & $\begin{array}{r}5.92 \\
(5.79-6.00)\end{array}$ & This study \\
\hline 1960-1985 & 12 & $\begin{array}{r}70950 \\
(70500-75425)\end{array}$ & $\begin{array}{r}2.17 \\
(1.57-2.57)\end{array}$ & $\begin{array}{r}121.5 \\
(92.93-166.8)\end{array}$ & $\begin{array}{r}45.5 \\
(32.5-56.8)\end{array}$ & $\begin{array}{r}128 \\
(102.3-173.5)\end{array}$ & $\begin{array}{r}2660 \\
(1948-5990)\end{array}$ & $\begin{array}{r}146 \\
(111.0-183.3)\end{array}$ & $\begin{array}{r}532 \\
(426.5-662.5)\end{array}$ & $\begin{array}{r}3.32 \\
(2.88-4.38)\end{array}$ & \\
\hline Before 1960 & 14 & $\begin{array}{r}69050 \\
(68400-69875)\end{array}$ & $\begin{array}{r}0.52 \\
(0.45-0.71)\end{array}$ & $\begin{array}{r}56.6 \\
(51.23-62.78)\end{array}$ & $\begin{array}{r}26 \\
(25.0-27.0)\end{array}$ & $\begin{array}{r}74.3 \\
(71.3-76.8)\end{array}$ & $\begin{array}{r}1630 \\
(1478-1823)\end{array}$ & $\begin{array}{r}71.5 \\
(69.0-75.8)\end{array}$ & $\begin{array}{r}282 \\
(258.5-289.3)\end{array}$ & $\begin{array}{r}2.41 \\
(2.35-2.45)\end{array}$ & \\
\hline \multicolumn{12}{|l|}{ MGGN-2018-29 } \\
\hline 1986 and after & 16 & $\begin{array}{r}70250 \\
(68450-70625)\end{array}$ & $\begin{array}{r}0.64 \\
(0.58-0.68)\end{array}$ & $\begin{array}{r}29.1 \\
(26.4-31.7)\end{array}$ & $\begin{array}{r}36 \\
(33.8-37.3)\end{array}$ & $\begin{array}{r}65.1 \\
(63.6-66.3)\end{array}$ & $\begin{array}{r}543 \\
(524-592)\end{array}$ & $\begin{array}{r}45.5 \\
(42.5-47.3)\end{array}$ & $\begin{array}{r}240 \\
(216.3-247.0)\end{array}$ & $\begin{array}{r}3.27 \\
(3.21-3.40)\end{array}$ & This study \\
\hline 1960-1985 & 13 & $\begin{array}{r}68000 \\
(65900-69600)\end{array}$ & $\begin{array}{r}0.86 \\
(0.71-1.05)\end{array}$ & $\begin{array}{r}24.3 \\
(20.4-26.5)\end{array}$ & $\begin{array}{r}37 \\
(36.0-37.0)\end{array}$ & $\begin{array}{r}56.4 \\
(54.9-59.3)\end{array}$ & $\begin{array}{r}584 \\
(564-607)\end{array}$ & $\begin{array}{r}41 \\
(40.0-41.0)\end{array}$ & $\begin{array}{r}243 \\
(214.0-250.0)\end{array}$ & $\begin{array}{r}3.03 \\
(2.76-3.10)\end{array}$ & \\
\hline Before 1960 & 1 & 71200 & 0.54 & 19.6 & 27 & 49.2 & 542 & 34 & 159 & 2.37 & \\
\hline \multicolumn{12}{|l|}{ MGGN-2018-30 } \\
\hline 1986 and after & 9 & $\begin{array}{r}69500 \\
(68500-70600)\end{array}$ & $\begin{array}{r}0.77 \\
(0.60-0.90)\end{array}$ & $\begin{array}{r}40.2 \\
(36.1-43.5)\end{array}$ & $\begin{array}{r}33 \\
(31.0-35.0)\end{array}$ & $\begin{array}{r}68.2 \\
(66.3-68.8)\end{array}$ & $\begin{array}{r}718 \\
(683-1250)\end{array}$ & $\begin{array}{r}50 \\
(48.0-52.0)\end{array}$ & $\begin{array}{r}250 \\
(228.0-258.0)\end{array}$ & $\begin{array}{r}3.07 \\
(3.04-3.39)\end{array}$ & This study \\
\hline $1960-1985$ & 7 & $\begin{array}{r}69600 \\
(69400-70500)\end{array}$ & $\begin{array}{r}1 \\
(0.80-1.34)\end{array}$ & $\begin{array}{r}32 \\
(31.2-37.1)\end{array}$ & $\begin{array}{r}34 \\
(30.5-34.5)\end{array}$ & $\begin{array}{r}58.3 \\
(55.3-62.8)\end{array}$ & $\begin{array}{r}621 \\
(620-641)\end{array}$ & $\begin{array}{r}46 \\
(43.5-48.0)\end{array}$ & $\begin{array}{r}225 \\
(213.5-2665)\end{array}$ & $\begin{array}{r}2.57 \\
(254-271)\end{array}$ & \\
\hline Before 1960 & 24 & $\begin{array}{r}68950 \\
(68150-70000)\end{array}$ & $\begin{array}{r}0.48 \\
(0.35-0.54)\end{array}$ & $\begin{array}{r}21.7 \\
(21.1-23.7)\end{array}$ & $\begin{array}{r}26 \\
(25.0-27.0)\end{array}$ & $\begin{array}{r}49 \\
(48.6-49.8)\end{array}$ & $\begin{array}{r}726 \\
(700-757)\end{array}$ & $\begin{array}{r}38 \\
(37.0-39.0)\end{array}$ & $\begin{array}{r}150.5 \\
(140.0-163.8)\end{array}$ & $\begin{array}{r}2.36 \\
(2.27-2.37)\end{array}$ & \\
\hline \multicolumn{12}{|l|}{ MGGN-2018-31 } \\
\hline 1986 and after & 8 & $\begin{array}{r}69800 \\
(67600-71525)\end{array}$ & $\begin{array}{r}0.6 \\
(0.52-0.70)\end{array}$ & $\begin{array}{r}28.9 \\
(27.9-31.7)\end{array}$ & $\begin{array}{r}32 \\
(29.5-34.0)\end{array}$ & $\begin{array}{r}64.5 \\
(61.6-65.4)\end{array}$ & $\begin{array}{r}695 \\
(625-1205)\end{array}$ & $\begin{array}{r}44.5 \\
(42.0-48.5)\end{array}$ & $\begin{array}{r}216.5 \\
(199.8-231.8)\end{array}$ & $\begin{array}{r}3.33 \\
(3.15-3.41)\end{array}$ & This study \\
\hline 1960-1985 & 7 & $\begin{array}{r}70800 \\
(70550-71600)\end{array}$ & $\begin{array}{r}0.85 \\
(0.65-0.98)\end{array}$ & $\begin{array}{r}29.7 \\
(28.3-33.3)\end{array}$ & $\begin{array}{r}34 \\
(32.5-37.0)\end{array}$ & $\begin{array}{r}55.5 \\
(55.2-58.2)\end{array}$ & $\begin{array}{r}551 \\
(547-573)\end{array}$ & $\begin{array}{r}45 \\
(44.0-45.5)\end{array}$ & $\begin{array}{r}224 \\
(208.5-248.5)\end{array}$ & $\begin{array}{r}2.63 \\
(2.61-2.76)\end{array}$ & \\
\hline Before 1960 & 25 & $\begin{array}{r}70600 \\
(69600-71600)\end{array}$ & $\begin{array}{r}0.4 \\
(0.27-0.55)\end{array}$ & $\begin{array}{r}21.6 \\
(19.5-23.1)\end{array}$ & $\begin{array}{r}27 \\
(27.0-29.0)\end{array}$ & $\begin{array}{r}49.7 \\
(48.9-50.9)\end{array}$ & $\begin{array}{r}628 \\
(614-642)\end{array}$ & $\begin{array}{r}38 \\
(36.0-39.0)\end{array}$ & $\begin{array}{r}148 \\
(135.0-163.0)\end{array}$ & $\begin{array}{r}2.36 \\
(2.27-2.40)\end{array}$ & \\
\hline \multicolumn{12}{|l|}{ MGGN-2018-32 } \\
\hline 1986 and after & 6 & $\begin{array}{r}67350 \\
(66025-68150)\end{array}$ & $\begin{array}{r}0.64 \\
(0.54-0.72)\end{array}$ & $\begin{array}{r}32.7 \\
(30.2-35.7)\end{array}$ & $\begin{array}{r}27 \\
(26.3-29.3)\end{array}$ & $\begin{array}{r}59.5 \\
(59.3-60.2)\end{array}$ & $\begin{array}{r}909 \\
(605-2085)\end{array}$ & $\begin{array}{r}42 \\
(40.3-43.8)\end{array}$ & $\begin{array}{r}203 \\
(193.5-211.8)\end{array}$ & $\begin{array}{r}2.7 \\
(2.58-2.99)\end{array}$ & This study \\
\hline 1960-1985 & 6 & $\begin{array}{r}69400 \\
(68650-70825)\end{array}$ & $\begin{array}{r}0.56 \\
(0.54-0.75)\end{array}$ & $\begin{array}{r}29.9 \\
(25.2-31.9)\end{array}$ & $\begin{array}{r}26.5 \\
(26.0-28.5)\end{array}$ & $\begin{array}{r}51.3 \\
(49.6-54.2)\end{array}$ & $\begin{array}{r}557 \\
(535-567)\end{array}$ & $\begin{array}{r}40 \\
(37.0-43.8)\end{array}$ & $\begin{array}{r}180.5 \\
(159.8-199.8)\end{array}$ & $\begin{array}{r}2.28 \\
(2.21-2.40)\end{array}$ & \\
\hline Before 1960 & 30 & $\begin{array}{r}69850 \\
(69025-70925)\end{array}$ & $\begin{array}{r}0.25 \\
(0.21-0.32)\end{array}$ & $\begin{array}{r}18.7 \\
(17.6-19.6)\end{array}$ & $\begin{array}{r}24 \\
(24.0-25.0)\end{array}$ & $\begin{array}{r}48.7 \\
(47.6-49.4)\end{array}$ & $\begin{array}{r}633 \\
(607-652)\end{array}$ & $\begin{array}{r}35 \\
(34.0-37.0)\end{array}$ & $\begin{array}{r}126 \\
(120.5-133.3)\end{array}$ & $\begin{array}{r}2.07 \\
(1.92-2.14)\end{array}$ & \\
\hline \multicolumn{12}{|l|}{ Total } \\
\hline 1986 and after & 145 & $\begin{array}{r}71100 \\
(67900-75200)\end{array}$ & $\begin{array}{r}1.1 \\
(0.75-1.40)\end{array}$ & $\begin{array}{r}68.5 \\
(42.6-93.0)\end{array}$ & $\begin{array}{r}41 \\
(33.0-55.0)\end{array}$ & $\begin{array}{r}125 \\
(67.8-175.8)\end{array}$ & $\begin{array}{r}1800 \\
(1120-4090)\end{array}$ & $\begin{array}{r}88 \\
(51.0-107.0)\end{array}$ & $\begin{array}{r}389 \\
(254.0-454.0)\end{array}$ & $\begin{array}{r}4.1 \\
(3.26-5.39)\end{array}$ & This study \\
\hline $1960-1985$ & 88 & $\begin{array}{r}70250 \\
(67925-71950)\end{array}$ & $\begin{array}{r}1.08 \\
(0.83-1.52)\end{array}$ & $\begin{array}{r}43.1 \\
(30.8-66.2)\end{array}$ & $\begin{array}{r}35.5 \\
(30.0-41.3)\end{array}$ & $\begin{array}{r}64.4 \\
(56.3-107.0)\end{array}$ & $\begin{array}{r}1030 \\
(595-2355)\end{array}$ & $\begin{array}{r}54.5 \\
(43.7-86.0)\end{array}$ & $\begin{array}{r}260 \\
(222.5-374.8)\end{array}$ & $\begin{array}{r}2.79 \\
(2.48-3.36)\end{array}$ & \\
\hline Before 1960 & 117 & $\begin{array}{r}69900 \\
\end{array}$ & $\begin{array}{r}0.44 \\
0.62\end{array}$ & $\begin{array}{r}21.7 \\
\end{array}$ & 26 & $\begin{array}{r}49.7 \\
\end{array}$ & $\begin{array}{r}669 \\
\end{array}$ & 38 & 148 & 2.34 & \\
\hline Grand total & 350 & $\begin{array}{r}(68600-71400) \\
70300 \\
(68300-72700)\end{array}$ & $\begin{array}{r}(0.27-0.62) \\
0.86 \\
(0.53-1.32)\end{array}$ & $\begin{array}{r}(19.5-41.0) \\
45.3 \\
(24.3-72.8)\end{array}$ & $\begin{array}{r}(24.0-28.0) \\
33 \\
(27.0-43.0)\end{array}$ & $\begin{array}{r}(48.6-68.5) \\
68.4 \\
(51.8-124.8)\end{array}$ & $\begin{array}{r}(631-1270) \\
1195 \\
(644-2490)\end{array}$ & $\begin{array}{r}(36.0-58.0) \\
55 \\
(40.0-91.0)\end{array}$ & $\begin{array}{r}(131.0-244.0) \\
258 \\
(176.2-393.5)\end{array}$ & $\begin{array}{r}(2.11-2.43) \\
3.04 \\
(2.36-3.93)\end{array}$ & This study \\
\hline $\begin{array}{l}\text { Laihianjoki estuary } \\
\text { Surface sediment; mi }\end{array}$ & $\begin{array}{c}1 \\
\text { roway }\end{array}$ & $\begin{array}{r}59900 \\
\text { ve } \mathrm{HNO}_{3} \text { digestion }\end{array}$ & 0.92 & 74.3 & 63.1 & n.d. & 788 & 130.5 & 461 & n.d. & Wallin et al. (2015) \\
\hline $\begin{array}{l}\text { Vöyrinjoki estuary } \\
\text { Site B, after } 1960\end{array}$ & 13 & $\begin{array}{r}86400 \\
(82900-87600)\end{array}$ & $\begin{array}{r}1.54 \\
(1.32-1.76)\end{array}$ & $\begin{array}{r}112.1 \\
(106.6-128.6)\end{array}$ & $\begin{array}{r}59.9 \\
(58.6-64.0)\end{array}$ & $\begin{array}{r}187 \\
(186-198)\end{array}$ & $\begin{array}{r}9013 \\
(6854-10923)\end{array}$ & $\begin{array}{r}83.9 \\
(80.1-98.5)\end{array}$ & $\begin{array}{r}529.1 \\
(493.6-592.0)\end{array}$ & n.d. & Nordmyr et al. (2008b) \\
\hline Four acid digestion & & & & & & & & & & & \\
\hline Bothnian Bay & 5 & n.d. & $0.8 \pm 0.3$ & n.d. & $46 \pm 15$ & n.d. & $8500 \pm 5300$ & n.d. & $216 \pm 92$ & $4.0 \pm 1.2$ & Leivuori and Niemistö (1995) \\
\hline Surface sediment, & & acid digestion, & mean cont & & & & & & & & \\
\hline Bothnian Sea & 5 & n.d. & $0.4 \pm 0.2$ & n.d. & $30 \pm 11$ & n.d. & $3000 \pm 1600$ & n.d. & $173 \pm 56$ & $2.3 \pm 1.0$ & Leivuori and Niemistö (1995) \\
\hline
\end{tabular}

Metal contents are in $\mathrm{mg} \mathrm{kg}^{-1}$ dry weight. Carbon content is in percentage (\%) dry weight. Note: n.d. - not determined. 
(Fig. 5). In contrast, median $\mathrm{Al}$ contents are essentially uniform in all the cores and between upper and lower sections.

When sediment cores are arranged according to distance from the Laihianjoki and Sulvanjoki rivers, the pattern of decreasing metal contents with increasing distance is evident (Fig. 6). The median metal contents also exceed several sediment quality guideline thresholds. The metal contents have not been normalized because the sediment samples contain more than $30 \%$ clay, and on median $3.7 \%$ of $\mathrm{C}$, which means that normalization coefficients according to the Finnish sediment dredging and dumping guidelines are close to 1 .

\section{Discussion}

Contents of trace metals known to be abundantly leached from AS soils ( $\mathrm{Al}, \mathrm{Cd}, \mathrm{Co}, \mathrm{Cu}, \mathrm{La}, \mathrm{Mn}, \mathrm{Ni}$, and $\mathrm{Zn}$ ) have been studied in sediment cores from the Kvarken Archipelago, which is the recipient sea area of the Laihianjoki and Sulvanjoki rivers. These rivers are frequently heavily loaded with a range of metals that certainly are derived from AS soils that are widespread in their catchment areas, given that there are no other significant metal-releasing activities such as old or current mines or metal industry activities (Roos and Åström, 2005).

\subsection{Metal distribution}

The median contents of $\mathrm{Al}$ are similar in the core sections deposited before the year 1960 and in 1986 and later, and the values show essentially no change with distance from the river mouths (Fig. 5). The vertical distribution of $\mathrm{Al}$ is similar to the other metals, with the highest values in the 1980s in the core from Varisselkä (MGGN-2017-20) but different at the other sites (Fig. 2). Clearly, the intensive artificial drainage of the AS soil landscape, which began in the 1960s (Saarinen et al., 2010; Yu et al., 2015), has not substantially influenced the delivery of Al to coring sites other than Varisselkä. IQR of Al contents in sections deposited in 1986 and later in all cores is $67900-75200 \mathrm{mg} \mathrm{kg}^{-1}$ (Table 2), and the maximum $\mathrm{Al}$ content is $110000 \mathrm{mg} \mathrm{kg}^{-1}$. A higher median $\mathrm{Al}$ content ( $86400 \mathrm{mg} \mathrm{kg}^{-1}$; Table 2 ) has been reported near the mouth of the Vöyrinjoki river (Nordmyr et al., 2008b), which is situated ca. $37 \mathrm{~km}$ northeast from the nearest coring site (Fig. 1b). This is in good agreement with previous observations, which show that $\mathrm{Al}$ is, to a large extent, deposited very close to river mouths together with organic material (Nordmyr et al., 2008a, b; Åström et al., 2012; Nystrand et al., 2016). Wallin et al. (2015) report the Al content of $59900 \mathrm{mg} \mathrm{kg}^{-1}$ for a single sample "from the first accumulation basin in the estuary" of the Laihianjoki river (Table 2), but do not provide coordinates or a map of the sampling location, which makes it difficult to assess the representativeness of the sample.
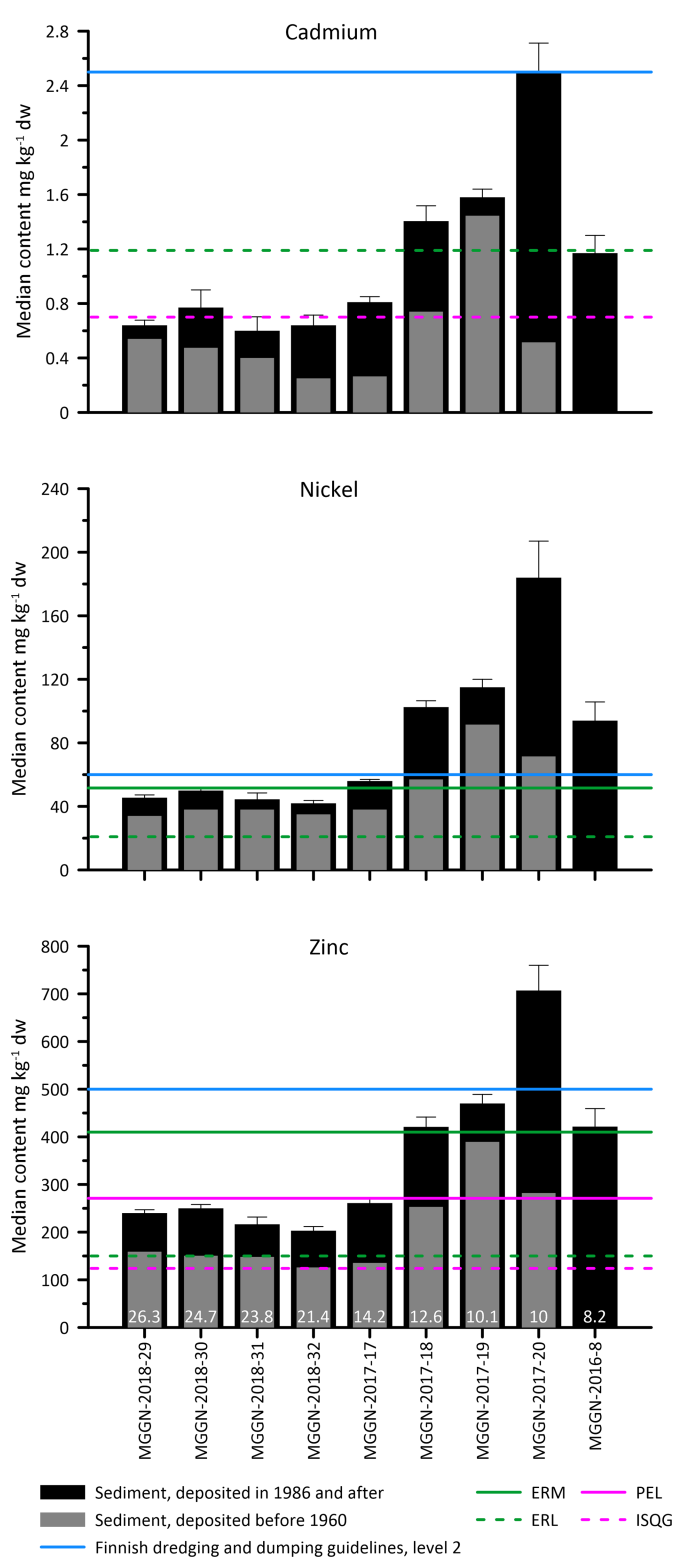

Figure 6. Median $\mathrm{Cd}, \mathrm{Ni}$, and $\mathrm{Zn}$ contents in sediment cores, arranged according to distance from the Laihianjoki and Sulvanjoki rivers, with sediment quality guidelines indicated. Black bars show median contents in core sections deposited in 1986 and later, whereas the narrower grey bars show contents in core sections deposited before 1960. Whiskers above the black bars indicate the upper quartile of the contents. Note that core MGGN-2016-8 does not contain sediments deposited before 1960 . White numbers in the $\mathrm{Zn}$ panel denote the distance to the closest river mouth in kilometres. The blue line indicates the level 2 threshold in Finnish sediment dredging and dumping guidelines (Ympäristöministeriö, 2015). Green solid and dashed lines indicate the North American effects range medium (ERM) and effects range low (ERL) thresholds, respectively (Long et al., 1995). Purple solid and dashed lines indicate the Canadian probable effect level (PEL) and interim sediment quality guideline (ISQG) thresholds, respectively (Canadian Council of Ministers of the Environment, 2001). 
Manganese median contents are enriched at the four sites closest to the rivers in the east (MGGN-2016-8, MGGN2017-18, MGGN-2017-19, and MGGN-2017-20) compared to cores collected farther out at sea (Fig. 5). The enrichment is stronger in the upper core sections deposited in 1986 and later than in the core sections deposited before 1960. The enrichment is in line with the previously documented increase in metal loading to estuaries in western Finland due to increased artificial drainage of the AS soil landscape that began in the 1960s (Yu et al., 2015, 2016). The vertical distribution of Mn shows elevated values in upper core sections, similar to the other metals at the easternmost sites (Fig. 2; MGGN-2017-18, MGGN-2017-19, and MGGN-2017-20). However, in cores farther out at sea in western Korshamnsfjärden and Gloppet, the vertical distribution of Mn is generally flat, except for a pronounced increase at the core tops. IQR of Mn in core sections deposited in 1986 and later in the easternmost sites is $3740-7300 \mathrm{mg} \mathrm{kg}^{-1}$, whereas it is $548-$ $1293 \mathrm{mg} \mathrm{kg}^{-1}$ at the sites farther out at sea. The maximum Mn content in the upper core sections is $14000 \mathrm{mg} \mathrm{kg}^{-1}$. Similar Mn contents to the easternmost sites have been reported from the open sea areas of Bothnian Sea and Bothnian Bay, with a mean of $3000 \pm 1600$ and $8500 \pm 5300 \mathrm{mg} \mathrm{kg}^{-1}$, respectively (Leivuori and Niemistö, 1995). Higher Mn contents (median $9013 \mathrm{mg} \mathrm{kg}^{-1}$; Table 2) have been reported near the mouth of the Vöyrinjoki river (Nordmyr et al., 2008b). Manganese enrichment in upper core sections is evident from Varisselkä (MGGN-2017-18) to eastern and middle Korshamnsfjärden (MGGN-2017-19 and MGGN-201720), which shows that it is transported for longer distances from the rivers than $\mathrm{Al}$. This observation is in line with previous studies, which demonstrate that Mn can travel a long distance before precipitation as Mn oxyhydroxides and the consequent deposition on the sea floor (Nordmyr et al., 2008a, b; Nystrand et al., 2016). Even farther out at sea, the strong increase in Mn at the core tops (Fig. 2) is due to the reductive dissolution of buried Mn oxyhydroxides and the associated release of $\mathrm{Mn}^{2+}$ into the porewater, with subsequent upward diffusion and oxidative precipitation of $\mathrm{Mn}$ as oxyhydroxides in the sediment surface layer (Widerlund and Ingri, 1996). $\mathrm{Mn}$ is the only metal from AS soils for which such redoxdriven migration has been previously observed in the area (Nordmyr et al., 2008b). The Mn content reported by Wallin et al. (2015) from the Laihianjoki estuary is comparably low (788 $\mathrm{mg} \mathrm{kg}^{-1}$; Table 2).

The median contents of $\mathrm{Cd}, \mathrm{Co}, \mathrm{Cu}, \mathrm{La}, \mathrm{Ni}$, and $\mathrm{Zn}$ are higher at the four easternmost sites closest to the rivers (MGGN-2016-8, MGGN-2017-18, MGGN-2017-19, and MGGN-2017-20) compared to those farther offshore (Fig. 5; see the Supplement). In contrast to Al and Mn, these metals are enriched in the upper core sections deposited in 1986 and later at all the coring sites, compared to the lower sections deposited before 1960. Vertical distributions of these metals show increasing upward trends beginning at ca. 1960 in all cores except in MGGN-2017-
19 (eastern Korshamnsfjärden), where the initial metal contents are high and variable with no clear trend until they begin to increase in the early 1980s (Fig. 2). IQRs of Cd, $\mathrm{Ni}$, and $\mathrm{Zn}$, for example, in core sections deposited in 1986 and later are $0.75-1.40,51-107$, and $254-454 \mathrm{mg} \mathrm{kg}^{-1}$, respectively (Table 2). Similar $\mathrm{Cd}$ contents have been reported from the Laihianjoki estuary $\left(0.92 \mathrm{mg} \mathrm{kg}^{-1}\right.$; Wallin et al., 2015) and the open-sea area of Bothnian Bay (mean $0.8 \pm 0.3 \mathrm{mg} \mathrm{kg}^{-1}$; Leivuori and Niemistö, 1995), whereas lower $\mathrm{Cd}$ contents have been reported from the open Bothnian Sea (0.4 $\pm 0.2 \mathrm{mg} \mathrm{kg}^{-1}$; Leivuori and Niemistö, 1995). A higher Ni content has been reported from the Laihianjoki estuary (130.5 $\mathrm{mg} \mathrm{kg}^{-1}$; Wallin et al., 2015), and higher $\mathrm{Zn}$ contents have been reported from the estuaries of Laihianjoki (461 mg kg-1, Wallin et al., 2015) and Vöyrinjoki (maximum $608.5 \mathrm{mg} \mathrm{kg}^{-1}$; Nordmyr et al., 2008b). However, the maximum $\mathrm{Cd}, \mathrm{Ni}$, and $\mathrm{Zn}$ contents in the upper core sections are generally 2-3 times higher than previously reported from the area, i.e. $3.11,245$, and $835 \mathrm{mg} \mathrm{kg}^{-1}$, respectively.

After the strong increase in sedimentary metal contents during the 1960s and 1970s, the metal contents and, thus, metal loading from the AS soils have stayed at the same level overall since the 1980s (Fig. 2). In Korshamnsfjärden (MGGN-2017-17, MGGN-2017-18, and MGGN-2017-19), the contents of $\mathrm{Co}, \mathrm{Ni}, \mathrm{La}$, and $\mathrm{Zn}$ generally continue to increase until the core top, whereas the increasing trends of $\mathrm{Cu}$ and $\mathrm{Cd}$ level out or begin to decrease at ca. 1986. In Gloppet (MGGN-2018-29 and MGGN-2018-31), more than $25 \mathrm{~km}$ from the river mouths, the contents of $\mathrm{Co}, \mathrm{Ni}$, and $\mathrm{La}$ vary at high values up to the core top, whereas $\mathrm{Zn}, \mathrm{Cu}$, and $\mathrm{Cd}$ begin to decrease from ca. 1986 onwards. An exception to this pattern is Varisselkä (MGGN-2017-20), where unexpectedly high contents of $\mathrm{Al}, \mathrm{Cd}, \mathrm{Co}, \mathrm{Cu}, \mathrm{La}, \mathrm{Ni}$, and $\mathrm{Zn}$ were deposited in the early to mid-1980s (Fig. 2). In this core, the metal contents decrease towards the core top; however, despite this, Varisselkä still has higher metal contents in the sediment surface than the other sites. The decrease in metal contents in Varisselkä parallels the decreasing share of terrestrial organic carbon since the 1980s, which suggests that the decrease in metal contents may be due to the reduced transport of metal-organic aggregates to the site (Sect. 5.2) as a result of, for example, the narrowing of the shallow channel to the southeast (Fig. 5) rather than a decrease in the metal loading to the archipelago. Had the metal loading to the sea area decreased, it would certainly be visible also in the Korshamnsfjärden cores, which it is not.

In AS soils worldwide, such as in Australia, Fe species are typically recognized as being a major product of acidic drainage and a major sink for mobilized metals (e.g. Bush et al., 2004; Mosley et al., 2018; Job et al., 2020). However, in boreal AS soils, the mobility of Fe is typically low (Österholm and Åström, 2002; Sohlenius and Öborn, 2004; Nordmyr et al., 2008b). The reason for this condition has not yet been fully established, but it is probably related to efficient oxidation of the mobile $\mathrm{Fe}^{2+}$ to the relatively insoluble $\mathrm{Fe}^{3+}$, 
and that, once formed, the oxidized form is protected from re-reduction. Consequently, the iron released from iron sulfide minerals is largely retained within, and is thus to only a limited extent leached from, the boreal AS soils. For example, Åström and Björklund (1996) have demonstrated that, in unfiltered water samples from a stream draining AS soils in the boreal zone, there is no increase in $\mathrm{Fe}$ concentration as the relative proportion of this soil type increases downstream. Furthermore, the majority of $\mathrm{Fe}$ transported by acidic rivers to the estuaries has been shown to precipitate and deposit close to river mouths (Nordmyr et al., 2008a; Åström et al., 2012; Nystrand et al., 2016). The seaward distribution pattern of $\mathrm{Fe}$ in the Kvarken Archipelago is comparable to that of $\mathrm{Al}$; there is no $\mathrm{Fe}$ enrichment in the upper core sections deposited in 1986 and later (IQR 40300-45 $600 \mathrm{mg} \mathrm{kg}^{-1}$; median $43200 \mathrm{mg} \mathrm{kg}^{-1}$ ) compared to the lower sections deposited before 1960 (IQR 43 300-47800 $\mathrm{mg} \mathrm{kg}^{-1}$; median $45600 \mathrm{mg} \mathrm{kg}^{-1}$ ), and there is no systematic decrease in the $\mathrm{Fe}$ content with distance from the river mouths (see the Supplement). Finally, the measured Fe contents in the sea area are not enriched compared to their parent AS soils, with a median $\mathrm{Fe}$ content of $38000 \mathrm{mg} \mathrm{kg}^{-1}$ (90th percentile $48100 \mathrm{mg} \mathrm{kg}^{-1}$; Åström and Björklund, 1997).

It is worth noting that permanent sediment deposition is today restricted to small patches in the eastern coastal Gulf of Bothnia due to the shallow water depths and the openness of the sea area to dominant southwesterly winds (waves; Kotilainen et al., 2012). As a consequence, finding coring sites in the area that are representative of the recent sediment deposition can be challenging without a guidance from seismoacoustic sub-bottom surveys such as those carried out here. For example, metal contents reported by Wallin et al. (2015) are generally lower than those measured here, although their sampling site was supposedly closer to the source rivers. The four-acid digestion method used in this study generally produces comparable results for metals from AS soils to previous studies that have aimed at analysing the total metal contents in sediments, although different methods were used (Cook et al., 1997; Nordmyr et al., 2008a, b).

\subsection{Metal transport mechanisms}

The similar distribution of $\mathrm{Cd}, \mathrm{Co}, \mathrm{Cu}, \mathrm{La}, \mathrm{Ni}$, and $\mathrm{Zn}$ in the studied sea area is supported by the PCA, which shows similar behaviour of the metals, particularly $\mathrm{Cd}, \mathrm{Ni}$, and $\mathrm{Co}$ (Fig. 3). Previous studies of water samples, sediment trap material, and sea floor sediments have concluded that $\mathrm{Cu}$ and La precipitate readily close to river mouths, whereas $\mathrm{Cd}, \mathrm{Co}$, $\mathrm{Ni}$, and $\mathrm{Zn}$ are preferentially transported a bit further out, where they most likely co-precipitate and are deposited with Mn oxyhydroxides (Nordmyr et al., 2008a, b; Nystrand et al., 2016). This study shows that $\mathrm{Cd}, \mathrm{Co}, \mathrm{Cu}, \mathrm{La}, \mathrm{Ni}$, and $\mathrm{Zn}$ all are enriched in sediment cores farther out at sea than $\mathrm{Mn}$, which strongly indicates that other mechanism(s), in addition to the precipitation of Mn oxyhydroxides, influence their seaward transport and distribution.

Field studies and geochemical modelling show that $\mathrm{Cd}$, $\mathrm{Co}, \mathrm{Cu}, \mathrm{La}, \mathrm{Ni}$, and $\mathrm{Zn}$ in AS-soil-impacted rivers are transformed from dissolved to particulate form as they are discharged to the sea (Nordmyr et al., 2008a, b; Nystrand et al., 2016). Seaward transport of suspended particles is highly dependent on hydrological conditions, with high discharge producing large plumes of river water by which metals can be transported far from the river mouths (Nystrand et al., 2016). Exceptionally large river plumes can be caused by extreme events such as that in the late autumn of 2006, when a severely dry summer (maximizing the oxidation of sulfides in the AS soils) was followed by a severe wet spell (Österholm and Åström, 2008; Saarinen et al., 2010), causing widespread fish kills in rivers and estuaries in western Finland. Some of the peaks observed in the metal vertical distributions in sediment cores (Fig. 2) may result from such extreme events; however, exceptional events hardly explain the overall metal enrichment in the cores.

The PLSR2 analysis, supported by hierarchical partitioning, shows that $\mathrm{Cd}, \mathrm{Co}, \mathrm{Cu}, \mathrm{Ni}$, and $\mathrm{Zn}$ are strongly positively correlated with sediment grains with sizes between 2 and $6 \mu \mathrm{m}$ (Fig. 4). In addition, the nutrients $\mathrm{C}$ and $\mathrm{N}$ have strong positive correlations with the same grain size range, which suggests that the metals are associated with organic particles. This observation is supported by recent studies, which demonstrate the importance of metal-organic matter aggregates in the land-to-sea transfer of trace metals, particularly in boreal environments (Jokinen et al., 2020). When acidic river water is discharged to the sea, dissolved $\mathrm{Al}$ and $\mathrm{Fe}$ precipitate and are deposited as oxyhydroxides as a consequence of neutralization by mixing with seawater (Nordmyr et al., 2008a; Åström et al., 2012; Nystrand et al., 2016), whereas trace metals may behave more conservatively and form complexes with organic matter (Simpson et al., 2014) that are also transformed from dissolved to particulate form as a result of the salinity-induced flocculation (Sholkovitz, 1976; Asmala et al., 2014). The produced low-density metal-organic aggregates can be transported by currents far from the river mouth, as has been demonstrated for the Kalix River in the Bothnian Bay (Gustafsson et al., 2000) and elsewhere (Wang et al., 2017; Pavoni et al., 2020a, b).

Organic aggregates in coastal environments are loosely bound and fragile and have a size range of tens to thousands of micrometres (Eisma, 1986; Mikkelsen et al., 2006; Lee et al., 2012). The aggregates are easily broken after deposition by benthic organisms (e.g. Rhoads and Boyer, 1982), by sediment compaction with burial, and, ultimately, by the grain size analysis to their constituent particles, which typically are smaller than $20 \mu \mathrm{m}$ (Eisma, 1986; Mikkelsen et al., 2006; Lee et al., 2012). The 2-6 $\mu \mathrm{m}$ size range identified here differs from the local phytoplankton community, which is dominated by species smaller than $2 \mu \mathrm{m}$ during summer and those larger than $10 \mu \mathrm{m}$ in winter and spring (Andersson 
et al., 1996; Paczkowska et al., 2017). Indeed, sample treatment with excess $\mathrm{H}_{2} \mathrm{O}_{2}$ prior to the grain size analysis largely leaves behind inorganic particles, such as mineral grains that are commonly found enclosed in organic aggregates (Eisma, 1986; Mikkelsen et al., 2006; Lee et al., 2012). The 2-6 $\mu \mathrm{m}$ size range is close to the size of lithic grains with a modal peak of $8 \mu \mathrm{m}$ that are transported by the Karjaanjoki river to the Pojoviken estuary in the southern Finland, where the lithic grains are passively enclosed in organic aggregates at the river mouth and then transported seaward (Joonas Virtasalo, personal communication, 2020). The $2-6 \mu \mathrm{m}$ range is slightly larger than the median sediment grain size, with the IQR of median grain size of the studied samples being 1.96$2.54 \mu \mathrm{m}$. The share of $2-6 \mu \mathrm{m}$ grains is relatively invariable in each core and is generally between $20 \%-25 \%$ (see the Supplement), which further indicates that the observed vertical metal enrichment patterns are not controlled by temporal changes in sediment transport but by external metal loading such as that from AS soils.

The importance of river-borne organic matter in the sea area is demonstrated by the large share of terrestrial organic carbon in the cores. IQR of the share of terrestrial organic carbon of the total organic $\mathrm{C}$ in the cores is $39.2 \%-47.8 \%$, which is substantially higher than in, for example, coastal sea areas of southern Finland, where the terrestrial share usually is less than $30 \%$ (Jilbert et al., 2018; Jokinen et al., 2018, 2020). The terrestrial share is highest in cores from eastern Korshamnsfjärden (MGGN-2017-19) and Varisselkä (MGGN-2017-20), which are the closest to the river mouths (Fig. 2). The share of terrestrial organic carbon decreases upward in core sections deposited in 1986 and later, largely mirroring the increase in total $\mathrm{C}$, which indicates that the increase in total organic $\mathrm{C}$ is largely driven by increasing phytoplankton production during the recent ca. 30 years, in line with the observed increasing nutrient levels in the inner Kvarken Archipelago since 1980 (Lundberg et al., 2009).

\subsection{Risk assessment}

Metals associated with particles are eventually settled and buried in sediments and are therefore less available for the aquatic biota. However, particulate metals in sediments may be toxic to benthic invertebrates via the gastrointestinal tract and skin (Eggleton and Thomas, 2004; Wallin et al., 2015). Metals may also be dissolved from sediments to the aqueous phase if sea floor physical-chemical conditions are altered or sediment is bioturbated (Eggleton and Thomas, 2004; de Souza Machado et al., 2016).

Finnish sediment dredging and dumping guidelines provide metal content thresholds for the assessment of the suitability of material for offshore dumping (Ympäristöministeriö, 2015). Level 2 thresholds in the guidelines are defined so that metal contents exceeding these levels cause acute toxicity in less than $5 \%$ of marine organisms. Zinc contents in the majority of the samples and $\mathrm{Cd}$ contents in half of the samples that were deposited in 1986 and later in Varisselkä (MGGN-2017-20) exceed the level 2 threshold, which means that these sediments are considered unsuitable for offshore disposal (Fig. 6). Nickel contents in almost half of the samples exceed the level 2 threshold as far as $14.2 \mathrm{~km}$ from the nearest river mouth (MGGN-2017-17; western Korshamnsfjärden).

Finnish stakeholders often use North American and Canadian guidelines when assessing the environmental impacts of metals in marine sediments because of similar geological environment (e.g. Vallius, 2015). The North American guidelines determine metal toxicity in sediment relative to two threshold levels, namely effects range low (ERL) and effects range medium (ERM). Metal contents exceeding the ERMs frequently result in adverse effects on biota, whereas metal contents between ERLs and ERMs occasionally result in adverse effects on biota, and metal contents below ERLs rarely result in adverse effects on biota (Long et al., 1995). The Canadian Guidelines for Protection of Aquatic Life consist of the Interim Sediment Quality Guidelines (ISQGs) and the Probable Effect Levels (PELs), which are used to evaluate the biological effects of a contaminant (Canadian Council of Ministers of the Environment, 2001). Contents exceeding the PELs frequently result in adverse effects on biota, whereas levels between the PELs and the ISQGs are associated with infrequently occurring adverse effects. Levels below the ISQG rarely cause adverse effects.

More than half of the measured $\mathrm{Zn}$ contents exceed the ERL and ISQG levels at each coring site, frequently even in the core sections deposited before 1960 (Fig. 6). Furthermore, the majority of measured $\mathrm{Zn}$ contents exceed the ERM and PEL levels as far as $12.6 \mathrm{~km}$ from the nearest river mouth (MGGN-2017-18; middle Korshamnsfjärden). The majority of measured Ni contents exceed the ERL at each coring site and the ERM as far as $14.2 \mathrm{~km}$ from the nearest river mouth (MGGN-2017-12; western Korshamnsfjärden). The majority of Cd contents exceed the ISQG as far as $24.7 \mathrm{~km}$ from the nearest river (MGGN-2018-30; Gloppet) and the ERL at $12.6 \mathrm{~km}$ from the nearest river (MGGN-2017-18; middle Korshamnsfjärden). It seems likely that metal loading from AS soils has detrimental effects on biota in the studied sea area. This simple assessment would benefit from determining the speciation of metals in sediments as it affects the toxicity (see Linge, 2008). Furthermore, instead of individual metals, the combined toxic effects of several metals and environmental factors should be considered (Chu and Chow, 2002). The ecotoxicological risk of metal loading from AS soils was previously assessed to be high in the area by Wallin et al. (2015).

\section{Conclusions}

Loading from AS soils has resulted in the strong enrichment of $\mathrm{Cd}, \mathrm{Co}, \mathrm{Cu}, \mathrm{La}, \mathrm{Mn}, \mathrm{Ni}$, and $\mathrm{Zn}$ in sediments of the Kvarken Archipelago. The loading intensified in the 1960s 
and 1970s, when previous studies show that intensive artificial drainage of the coastal AS soil landscape began. Unlike the case for many AS soils worldwide, $\mathrm{Fe}$ is not enriched in the recipient sea area.

The metal deposition has remained at more or less the same level since the 1980s with fine-scale variability in contents, both among the metals and sampling sites. Metal transport from the Laihianjoki and Sulvanjoki rivers towards the open sea largely takes place along Korshamnsfjärden. The metal enrichment in sea floor sediments is currently visible at more than $25 \mathrm{~km}$ distance from the rivers. Comparison to sediment quality guidelines shows that metal contents in the majority of analysed sub-samples are sufficiently high to very likely have detrimental effects on marine biota more than $12 \mathrm{~km}$ from the river mouths. The dynamic nature of the patchy sediment deposition, the rapid uplift of the region, and the predicted increase in storm wave erosion with climate change imply that these sediments are potential future sources of metals to the marine ecosystem. Furthermore, acidic runoff and metal loading from acid sulfate soils have been predicted to increase with the climate change.

Previous studies have identified Mn oxyhydroxides as a mechanism of metal transport and deposition seaward from the river mouths in the area. This study shows that $\mathrm{Cd}, \mathrm{Co}$, $\mathrm{Cu}, \mathrm{La}, \mathrm{Ni}$, and $\mathrm{Zn}$ are transported further out at sea than $\mathrm{Mn}$, which requires an additional mechanism of metal transport. The strong association of the metals and nutrients to sediment grains of the same size range $(2-6 \mu \mathrm{m})$ suggests that the transformation of dissolved organic matter and metals to metal-organic aggregates at the river mouths is the key mechanism of seaward trace metal transport. The large share of terrestrial organic carbon of the total organic $\mathrm{C}$ in these sediments (interquartile range $39 \%-48 \%$ ) highlights the importance of riverine organic matter supply.

Data availability. Multi-element and grain size data are available from PANGAEA (Virtasalo et al., 2020a, b).

Supplement. The supplement related to this article is available online at: https://doi.org/10.5194/bg-17-6097-2020-supplement.

Author contributions. JV wrote the original draft, conceptualized the study, led the investigation, conducted the formal analysis, and acquired funding. PÖ and MA assisted with the reviewing and editing of the paper and also the conceptualization of the study. AK contributed to the reviewing and editing of the paper and assisted with the investigation, and was responsible for the funding acquisition and administration of the project.

Competing interests. The authors declare that they have no conflict of interest.
Acknowledgements. This study resulted from the SmartSea project, funded by the Strategic Research Council at the Academy of Finland. Mats E. Åström additionally acknowledges the Swedish Research Council Formas (grant no. 2018-00760). The study has utilized research infrastructure facilities provided by the Finnish Marine Research Infrastructure (FINMARI) network. Help from the crew of R/V Geomari and those who assisted in the fieldwork is gratefully acknowledged. Satu Vuoriainen carried out the ${ }^{137} \mathrm{Cs}$ analyses. Thomas Job, Anders Widerlund, and one anonymous reviewer are thanked for the constructive comments that helped improve the paper.

Financial support. This research has been supported by the Strategic Research Council at the Academy of Finland (grant no. 292 985).

Review statement. This paper was edited by Caroline P. Slomp and reviewed by Thomas Job and one anonymous referee.

\section{References}

Andersson, A., Hajdu, S., Haecky, P., Kuparinen, J., and Wikner, J.: Succession and growth limitation of phytoplankton in the Gulf of Bothnia (Baltic Sea), Mar. Biol., 126, 791-801, https://doi.org/10.1007/BF00351346, 1996.

Andriesse, W. and van Mensvoort, M. E. F.: Acid sulfate soils: distribution and extent, in: Encyclopedia of Soil Science, edited by: Lal, R., CRC Press, Boca Raton, USA, 14-19, https://doi.org/10.1081/E-ESS3-120006641, 2006.

Asmala, E., Bowers, D. G., Autio, R., Kaartokallio, H., and Thomas, D. N.: Qualitative changes of riverine dissolved organic matter at low salinities due to flocculation, J. Geophys. Res.-Biogeosci., 119, 1919-1933, https://doi.org/10.1002/2014JG002722, 2014.

Åström, M. and Björklund, A.: Hydrogeochemistry of a stream draining sulfide-bearing postglacial sediments in Finland, Water Air Soil Poll., 89, 233-246, https://doi.org/10.1007/BF00171634, 1996.

Åström, M. and Björklund, A.: Geochemistry and acidity of sulphide-bearing postglacial sediments of western Finland, Environ. Geochem. Hlth., 19, 155-164, https://doi.org/10.1023/A:1018462824486, 1997.

Åström, M. and Corin, N.: Abundance, sources and speciation of trace elements in humus-rich streams affected by acid sulphate soils, Aquat. Geochem., 6, 367-383, https://doi.org/10.1023/A:1009658231768, 2000.

Åström, M. E., Österholm, P., Gustafsson, J. P., Nystrand, M., Peltola, P., Nordmyr, L., and Boman, A.: Attenuation of rare earth elements in a boreal estuary, Geochim. Cosmochim. Ac., 96, 105-119, https://doi.org/10.1016/j.gca.2012.08.004, 2012.

Blott, S. J. and Pye, K.: GRADISTAT: a grain size distribution and statistics package for the analysis of unconsolidated sediments, Earth Surf. Proc. Land., 26, 1237-1248, https://doi.org/10.1002/esp.261, 2001.

Blott, S. J. and Pye, K.: Particle size scales and classification of sediment types based on particle size distributions: review 
and recommended procedures, Sedimentology, 59, 2071-2096, https://doi.org/10.1111/j.1365-3091.2012.01335.x, 2012.

Boman, A., Fröjdö, S., Backlund, K., and Åström, M. E.: Impact of isostatic land uplift and artificial drainage on oxidation of brackish-water sediments rich in metastable iron sulfide, Geochim. Cosmochim. Ac., 74, 1268-1281, https://doi.org/10.1016/j.gca.2009.11.026, 2010.

Breilin, O., Kotilainen, A., Nenonen, K., and Räsänen, M.: The unique moraine morphology, stratotypes and ongoing geological processes at the Kvarken Archipelago on the land uplift area in the western coast of Finland, in: Proceedings of the Workshop Organized within the Finnish National Committee for Quaternary Research (INQUA), Kilpisjärvi, Finland, 13-14 January 2005, 97-111, 2005.

Bush, R. T., Fyfe, D., and Sullivan, L. A.: Occurrence and abundance of monosulfidic black ooze in coastal acid sulfate soil landscapes, Aust. J. Soil Res., 42, 609-616, https://doi.org/10.1071/SR03077, 2004.

Canadian Council of Ministers of the Environment: Canadian sediment quality guidelines for the protection of aquatic life: summary tables, Updated, available at: http://st-ts.ccme.ca/en/index. html (last access: 1 December 2020), Canadian Council of Ministers of the Environment, Winnipeg, Canada, 2001.

Chevan, A. and Sutherland, M.: Hierarchical Partitioning, Am. Stat., 45, 90-96, https://doi.org/10.2307/2684366, 1991.

Chu, K. W. and Chow, K. L.: Synergistic toxicity of multiple heavy metals is revealed by a biological assay using a nematode and its transgenic derivative, Aquat. Toxicol., 61, 53-64, https://doi.org/10.1016/S0166-445X(02)00017-6, 2002.

Cook, J. M., Gardner, M. J., Griffiths, A. H., Jessep, M. A., Ravenscroft, J. E., and Yates, R.: The comparability of sample digestion techniques for the determination of metals in sediments, Mar. Pollut. Bull., 34, 637-644, https://doi.org/10.1016/S0025326X(96)00186-5, 1997.

Dent, D. L. and Pons, L. J.: A world perspective on acid sulphate soils, Geoderma., 67, 263-276, https://doi.org/10.1016/00167061(95)00013-E, 1995.

de Souza Machado, A. A., Spencer, K., Kloas, W., Toffolon, M., and Zarfl, C.: Metal fate and effects in estuaries: a review and conceptual model for better understanding of toxicity, Sci. Total Environ., 541, 268-281, https://doi.org/10.1016/j.scitotenv.2015.09.045, 2016.

Eggleton, J. and Thomas, K. V.: A review of factors affecting the release and bioavailability of contaminants during sediment disturbance events, Environ. Int., 30, 973-980, https://doi.org/10.1016/j.envint.2004.03.001, 2004.

Eisma, D.: Flocculation and de-flocculation of suspended matter in estuaries, Neth. J. Sea Res., 20, 183-199, https://doi.org/10.1016/0077-7579(86)90041-4, 1986.

Fältmarsch, R. M., Åström, M. E., and Vuori, K.-M.: Environmental risks of metals mobilised from acid sulphate soils in Finland: a literature review, Boreal. Environ. Res., 13, 444-456, 2008.

Filzmoser, P., Hron, K., and Reimann, C.: Principal component analysis for compositional data with outliers, Environmetrics, 20, 621-632, https://doi.org/10.1002/env.966, 2009.

Filzmoser, P., Hron, K., and Templ, M.: Applied Compositional Data Analysis, with Worked Examples in R, Springer, Cham, Switzerland, https://doi.org/10.1007/978-3-319-96422-5, 2018.
Folk, R. L. and Ward, W. C.: Brazos river bar: a study in the significance of grain size parameters, J. Sediment. Petrol., 27, 3-26, https://doi.org/10.1306/74D706462B21-11D7-8648000102C1865D, 1957.

Goñi, M. A., Teixeira, M. J., and Perkey, D. W.: Sources and distribution of organic matter in a river-dominated estuary (Winyah Bay, SC, USA), Estuar. Coast. Shelf S., 57, 1023-1048, https://doi.org/10.1016/S0272-7714(03)00008-8, 2003.

Gustafsson, Ö., Widerlund, A., Andersson, P. S., Ingri, J., Roos, P., and Ledin, A.: Colloid dynamics and transport of major elements through a boreal river-brackish bay mixing zone, Mar. Chem., 71, 1-21, https://doi.org/10.1016/S0304-4203(00)00035-9, 2000.

Hall, G. E. M., Vaive, J. E., Beer, R., and Hoashi, M.: Selective leaches revisited, with emphasis on the amorphous Fe oxyhydroxide phase extraction, J. Geochem. Explor., 56, 59-78, https://doi.org/10.1016/0375-6742(95)00050-X, 1996.

Häusler, K., Moros, M., Wacker, L., Hammerschmidt, L., Dellwig, O., Leipe, T., Kotilainen, A., and Arz, H. W.: Mid- to late Holocene environmental separation of the northern and central Baltic Sea basins in response to differential land uplift, Boreas, 46, 111-128, 10.1111/bor.12198, 2017.

Holby, O. and Evans, S.: The vertical distribution of Chernobylderived radionuclides in a Baltic Sea sediment, J. Environ. Radioactiv., 33, 129-145, https://doi.org/10.1016/0265931X(95)00089-S, 1996

Hudd, R. and Kjellman, J.: Bad matching between hatching and acidification: a pitfall for the burbot, Lota lota, off the river Kyrönjoki, Baltic Sea, Fish. Res., 55, 153-160, https://doi.org/10.1016/S0165-7836(01)00303-4, 2002.

Jilbert, T., Asmala, E., Schröder, C., Tiihonen, R., Myllykangas, J.P., Virtasalo, J. J., Kotilainen, A., Peltola, P., Ekholm, P., and Hietanen, S.: Impacts of flocculation on the distribution and diagenesis of iron in boreal estuarine sediments, Biogeosciences, 15, 1243-1271, https://doi.org/10.5194/bg-15-1243-2018, 2018.

Job, T., Penny, D., and Morgan, B.: Geochemical signatures of acidic drainage recorded in estuarine sediments after an extreme drought, Sci. Total Environ., 749, 141435, https://doi.org/10.1016/j.scitotenv.2020.141435, 2020.

Jokinen, S. A., Virtasalo, J. J., Jilbert, T., Kaiser, J., Dellwig, O., Arz, H. W., Hänninen, J., Arppe, L., Collander, M., and Saarinen, T.: A 1500-year multiproxy record of coastal hypoxia from the northern Baltic Sea indicates unprecedented deoxygenation over the 20th century, Biogeosciences, 15, 3975-4001, https://doi.org/10.5194/bg-15-3975-2018, 2018.

Jokinen, S. A., Jilbert, T., Tiihonen-Filppula, R., and Koho, K.: Terrestrial organic matter input drives sedimentary trace metal sequestration in a human-impacted boreal estuary, Sci. Total Environ., 717, 137047, https://doi.org/10.1016/j.scitotenv.2020.137047, 2020.

Kakkuri, J.: Fennoscandian land uplift: past, present and future, in: From the Earth's Core to Outer Space, edited by: Haapala, I., Springer, Berlin, Heidelberg, 127-136, https://doi.org/10.1007/978-3-642-25550-2_8, 2012.

Klaminder, J., Appleby, P., Crook, P., and Renberg, I.: Postdeposition diffusion of ${ }^{137} \mathrm{Cs}$ in lake sediment: implications for radiocaesium dating, Sedimentology, 59, 2259-2267, https://doi.org/10.1111/j.1365-3091.2012.01343.x, 2012.

Kotilainen, A. T., Kaskela, A. M., Bäck, S., and Leinikki, J.: Submarine De Geer moraines in the Kvarken Archipelago, the Baltic 
Sea, in: Seafloor Geomorphology as Benthic Habitat: GeoHab Atlas of Seafloor Geomorphic Features and Benthic Habitats, edited by: Harris, P. T. and Baker, E. D., Elsevier, Amsterdam, The Netherlands, 289-298, https://doi.org/10.1016/B978-0-12385140-6.00017-7, 2012.

Lee, B. J., Fettweis, M., Toorman, E., and Molz, F. J.: Multimodality of a particle size distribution of cohesive suspended particulate matters in a coastal zone, J. Geophys. Res., 117, C03014, https://doi.org/10.1029/2011JC007552, 2012.

Lehoux, A. P., Petersen, K., Leppänen, M. T., Snowball, I., and Olsen, M.: Status of contaminated marine sediments in four Nordic countries: assessments, regulations, and remediation approaches, J. Soil. Sediment., 20, 2619-2629, https://doi.org/10.1007/s11368-020-02594-3, 2020.

Leivuori, M. and Niemistö, L.: Sedimentation of trace metals in the Gulf of Bothnia, Chemosphere, 31, 3839-3856, https://doi.org/10.1016/0045-6535(95)00257-9, 1995.

Linge, K. L.: Methods for investigating trace element binding in sediments, Crit. Rev. Env. Sci. Tec., 38, 165-196, https://doi.org/10.1080/10643380601174780, 2008.

Long, E. R., Macdonald, D. D., Smith, S. L., and Calder, F. D.: Incidence of adverse biological effects within ranges of chemical concentrations in marine and estuarine sediments, Environ. Manage., 19, 81-97, https://doi.org/10.1007/BF02472006, 1995.

Lundberg, C., Jakobsson, B.-M., and Bonsdorff, E.: The spreading of eutrophication in the eastern coast of the Gulf of Bothnia, northern Baltic Sea - an analysis in time and space, Estuar. Coast. Shelf S., 82, 152-160, https://doi.org/10.1016/j.ecss.2009.01.005, 2009.

Mäkinen, J. and Saaranen, V.: Determination of post-glacial land uplift from the three precise levellings in Finland, J. Geodesy, 72, 516-529, https://doi.org/10.1007/s001900050191, 1998.

Michael, P. S., Fitzpatrick, R. W., and Reid, R. J.: Effects of live wetland plant macrophytes on acidification, redox potential and sulphate content in acid sulphate soils, Soil Use Manage., 33, 471-481, https://doi.org/10.1111/sum.12362, 2017.

Mikkelsen, O. A., Hill, P. S., and Milligan, T. G.: Single-grain, microfloc and macrofloc volume variations observed with a LISST-100 and a digital floc camera, J. Sea Res., 55, 87-102, https://doi.org/10.1016/j.seares.2005.09.003, 2006.

Mosley, L. M., Biswas, T. K., Dang, T., Palmer, D., Cummings, C., Daly, R., Simpson, S., and Kirby, J.: Fate and dynamics of metal precipitates arising from acid drainage discharges to a river system, Chemosphere, 212, 811-820, https://doi.org/10.1016/j.chemosphere.2018.08.146, 2018.

Nally, R. M. and Walsh, C. J.: Hierarchical partitioning public-domain software, Biodivers. Conserv., 13, 659-660, https://doi.org/10.1023/B:BIOC.0000009515.11717.0b, 2004.

Nordmyr, L., Åström, M., and Peltola, P.: Metal pollution of estuarine sediments caused by leaching of acid sulphate soils, Estuar. Coast. Shelf S., 76, 141-152, https://doi.org/10.1016/j.ecss.2007.07.002, 2008a.

Nordmyr, L., Österholm, P., and Åström, M.: Estuarine behaviour of metal loads leached from coastal lowland acid sulphate soils, Mar. Environ. Res., 66, 378-393, https://doi.org/10.1016/j.marenvres.2008.06.001, 2008b.

Nystrand, M. I., Österholm, P., Yu, C., and Åström, M.: Distribution and speciation of metals, phosphorus, sulfate and organic material in brackish estuary water af- fected by acid sulfate soils, Appl. Geochem., 66, 264-274, https://doi.org/10.1016/j.apgeochem.2016.01.003, 2016.

Ojala, A. E. K., Palmu, J.-P., ̊̊berg, A., Åberg, S., and Virkki, H.: Development of an ancient shoreline database to reconstruct the Litorina Sea maximum extension and the highest shoreline of the Baltic Sea basin in Finland, Bull. Geol. Soc. Finl., 85, 127-144, https://doi.org/10.17741/bgsf/85.2.002, 2013.

Ojala, A. E. K., Luoto, T. P., and Virtasalo, J. J.: Establishing a high-resolution surface sediment chronology with multiple dating methods - testing ${ }^{137} \mathrm{Cs}$ determination with Nurmijärvi clastic-biogenic varves, Quat. Geochronol., 37, 32-41, https://doi.org/10.1016/j.quageo.2016.10.005, 2017.

Olsson, T., Jakkila, J., Veijalainen, N., Backman, L., Kaurola, J., and Vehviläinen, B.: Impacts of climate change on temperature, precipitation and hydrology in Finland - studies using bias corrected Regional Climate Model data, Hydrol. Earth Syst. Sci., 19, 3217-3238, https://doi.org/10.5194/hess-19-3217-2015, 2015.

Österholm, P. and Åström, M.: Spatial trends and losses of major and trace elements in agricultural acid sulphate soils distributed in the artificially drained Rintala area, W. Finland, Appl. Geochem., 17, 1209-1218, https://doi.org/10.1016/S08832927(01)00133-0, 2002.

Österholm, P. and Åström, M.: Meteorological impacts on the water quality in the Pajuluoma acid sulphate area, W. Finland, Appl. Geochem., 23, 1594-1606, https://doi.org/10.1016/j.apgeochem.2008.01.011, 2008.

Paczkowska, J., Rowe, O., Schlüter, L., Legrand, C., Karlson, B., and Andersson, A.: Allochthonous matter: an important factor shaping the phytoplankton community in the Baltic Sea, J. Plankton Res., 39, 23-34, https://doi.org/10.1093/plankt/fbw081, 2017.

Pavoni, E., Crosera, M., Petranich, E., Adami, G., Faganeli, J., and Covelli, S.: Partitioning and mixing behaviour of trace elements at the Isonzo/Soča River mouth (Gulf of Trieste, northern Adriatic Sea), Mar. Chem., 223, 103800, https://doi.org/10.1016/j.marchem.2020.103800, 2020a.

Pavoni, E., Crosera, M., Petranich, E., Oliveri, P., Klun, K., Faganeli, J., Covelli, S., and Adami, G.: Trace elements in the estuarine systems of the Gulf of Trieste (northern Adriatic Sea): a chemometric approach to depict partitioning and behaviour of particulate, colloidal and truly dissolved fractions, Chemosphere, 252, 126517, https://doi.org/10.1016/j.chemosphere.2020.126517, 2020b.

Pirinen, P., Simola, H., Aalto, J., Kaukoranta, J.-P., Karlsson, P., and Ruuhela, R.: Climatological statistics of Finland 1981-2010, Reports 2012:1, Finnish Meteorological Institute, Helsinki, Finland, 83 pp., 2012.

Rhoads, D. C. and Boyer, L. F.: The effects of marine benthos on physical properties of sediments: a successional perspective, in: Animal-Sediment Relations, edited by: McCall, P. L. and Tevesz, M. J. S., Springer, Boston, MA, 3-52, https://doi.org/10.1007/978-1-4757-1317-6_1, 1982.

Roos, M. and Åström, M.: Hydrochemistry of rivers in an acid sulphate soil hotspot area in western Finland, Agr. Food Sci., 14, 24-33, https://doi.org/10.2137/1459606054224075, 2005.

Ruosteenoja, K., Vihma, T., and Venäläinen, A.: Projected changes in European and North Atlantic seasonal wind climate derived from CMIP5 simulations, J. Climate, 32, 6467-6490, https://doi.org/10.1175/JCLI-D-19-0023.1, 2019. 
Saarnisto, M. and Saarinen, T.: Deglaciation chronology of the Scandinavian Ice Sheet from the Lake Onega Basin to the Salpausselkä end moraines, Global Planet. Change, 31, 387-405, https://doi.org/10.1016/S0921-8181(01)00131-X, 2001.

Saarinen, T., Vuori, K.-M., Alasaarela, E., and Kløve, B.: Longterm trends and variation of acidity, $\mathrm{COD}_{M n}$ and colour in coastal rivers of Western Finland in relation to climate and hydrology, Sci. Total Environ., 408, 5019-5027, https://doi.org/10.1016/j.scitotenv.2010.07.009, 2010.

Sauramo, M.: The Quaternary geology of Finland, Bulletin de la Commission Géologique de Finlande, 86, 1-110, 1929.

Sholkovitz, E. R.: Flocculation of dissolved organic and inorganic matter during the mixing of river water and seawater, Geochim. Cosmochim. Ac., 40, 831-845, https://doi.org/10.1016/00167037(76)90035-1, 1976

Simpson, S. L., Vardanega, C. R., Jarolimek, C., Jolley, D. F., Angel, B. M., and Mosley, L. M.: Metal speciation and potential bioavailability changes during discharge and neutralization of acidic drainage water, Chemosphere, 103, 172-180, https://doi.org/10.1016/j.chemosphere.2013.11.059, 2014.

Sohlenius, G. and Öborn, I.: Geochemistry and partitioning of trace metals in acid sulphate soils in Sweden and Finland before and after sulphide oxidation, Geoderma, 122, 167-175, https://doi.org/10.1016/j.geoderma.2004.01.006, 2004.

Soil Survey Staff: Soil taxonomy: A basic system of soil classification for making and interpreting soil surveys, 2nd edition, Natural Resources Conservation Service, US Department of Agriculture Handbook 436, U.S. Government Printing Office, Washington, DC, 1999.

Stroeven, A. P., Hättestrand, C., Kleman, J., Heyman, J., Fabel, D., Fredin, O., Goodfellow, B. W., Harbor, J. M., Jansen, J. D., Olsen, L., Caffee, M. W., Fink, D., Lundqvist, J., Rosqvist, G. C., Strömberg, B., and Jansson, K. N.: Deglaciation of Fennoscandia, Quaternary Sci. Rev., 147, 91-121, https://doi.org/10.1016/j.quascirev.2015.09.016, 2016.

Sutela, T. and Vehanen, T.: The effects of acidity and aluminium leached from acid-sulphate soils on riverine fish assemblages, Boreal Environ. Res., 22, 385-391, 2017.

Tenenhaus, M.: La régression PLS: theorie et practique, Editions Technip, Paris, France, 1998.

Vallius, H.: Applying sediment quality guidelines on soft sediments of the Gulf of Finland, Baltic Sea, Mar. Pollut. Bull., 98, 314 319, https://doi.org/10.1016/j.marpolbul.2015.06.036, 2015.

Virtasalo, J. J., Kohonen, T., Vuorinen, I., and Huttula, T.: Sea bottom anoxia in the Archipelago Sea, northern Baltic Sea: implications for phosphorus remineralization at the sediment surface, Mar. Geol., 224, 103-122, https://doi.org/10.1016/j.margeo.2005.07.010, 2005.

Virtasalo, J. J., Kotilainen, A. T., Räsänen, M. E., and Ojala, A. E. K.: Late-glacial and post-glacial deposition in a large, low relief, epicontinental basin: the northern Baltic Sea, Sedimentology, 54, 1323-1344, https://doi.org/10.1111/j.1365-3091.2007.00883.x, 2007.
Virtasalo, J. J., Ryabchuk, D., Kotilainen, A. T., Zhamoida, V., Grigoriev, A., Sivkov, V., and Dorokhova, E.: Middle Holocene to present sedimentary environment in the easternmost Gulf of Finland (Baltic Sea) and the birth of the Neva River, Mar. Geol., 350, 84-95, https://doi.org/10.1016/j.margeo.2014.02.003, 2014.

Virtasalo, J. J., Åström, M. E., Österholm, P., and Kotilainen, A. T.: Multielement data of sediment samples from the Kvarken Archipelago, eastern Gulf of Bothnia, impacted by metal loading from acid sulphate soils, PANGAEA, https://doi.pangaea.de/10.1594/PANGAEA.920857, 2020a.

Virtasalo, J. J., Åström, M. E., Österholm, P., and Kotilainen, A. T.: Grain size data of sediment samples from the Kvarken Archipelago, eastern Gulf of Bothnia, impacted by metal loading from acid sulphate soils, PANGAEA, https://doi.pangaea.de/10.1594/PANGAEA.920850, 2020b.

Wallin, J., Karjalainen, A. K., Schultz, E., Järvistö, J., Leppänen, M., and Vuori, K.-M.: Weight-of-evidence approach in assessment of ecotoxicological risks of acid sulphate soils in the Baltic Sea river estuaries, Sci. Total Environ., 508, 452-461, https://doi.org/10.1016/j.scitotenv.2014.11.073, 2015.

Wang, W., Chen, M., Guo, L., and Wang, W.-X.: Size partitioning and mixing behavior of trace metals and dissolved organic matter in a South China estuary, Sci. Total Environ., 603/604, 434-444, https://doi.org/10.1016/j.scitotenv.2017.06.121, 2017.

Widerlund, A. and Ingri, J.: Redox cycling of iron and manganese in sediments of the Kalix River estuary, northern Sweden, Aquat Geochem., 2, 185-201, https://doi.org/10.1007/BF00121631, 1996.

Yli-Halla, M., Puustinen, M., and Koskiaho, J.: Area of cultivated acid sulfate soils in Finland, Soil Use Manage., 15, 62-67, https://doi.org/10.1111/j.1475-2743.1999.tb00065.x, 1999.

Ympäristöministeriö: Sedimenttien ruoppaus- ja läjitysohje, Ympäristöhallinnon ohjeita 1/2015, Finnish Ministry of the Environment, Helsinki, available at: https://julkaisut.valtioneuvosto. fi/handle/10138/154833 (last access: 1 December 2020), 72 pp., 2015.

Yu, C., Virtasalo, J. J., Karlsson, T., Peltola, P., Österholm, P., Burton, E. D., Arppe, L., Hogmalm, J. K., Ojala, A. E. K., and Åström, M. E.: Iron behavior in a northern estuary: large pools of non-sulfidized $\mathrm{Fe}$ (II) associated with organic matter, Chem. Geol., 413, 73-85, https://doi.org/10.1016/j.chemgeo.2015.08.013, 2015.

Yu, C., Virtasalo, J. J., Österholm, P., Burton, E. D., Peltola, P., Ojala, A. E. K., Hogmalm, J. K., and Åström, M. E.: Manganese accumulation and solid-phase speciation in a $3.5 \mathrm{~m}$ thick mud sequence from the estuary of an acidic and $\mathrm{Mn}$ rich creek, northern Baltic Sea, Chem. Geol., 437, 56-66, https://doi.org/10.1016/j.chemgeo.2016.05.016, 2016. 